\title{
Iterative land proxy based reconstruction of SST for the simulation of terrestrial Holocene climate
}

K. Haberkorn ${ }^{1}$, C. Lemmen ${ }^{2}$, R. Blender ${ }^{1}$, and K. Fraedrich ${ }^{1}$

${ }^{1}$ Meteorological Institute, KlimaCampus, University of Hamburg, Grindelberg 5, 20144 Hamburg, Germany

${ }^{2}$ Helmholtz Zentrum Geesthacht, Institute of Coastal Research, Max-Planck-Str. 1, 21502 Geesthacht, Germany

Received: 7 November 2011 - Accepted: 23 February 2012 - Published: 5 March 2012 Correspondence to: K. Haberkorn (kerstin.haberkorn@ zmaw.de)

Published by Copernicus Publications on behalf of the European Geosciences Union.
Reconstruction of SST for terrestrial Holocene climate

K. Haberkorn et al.

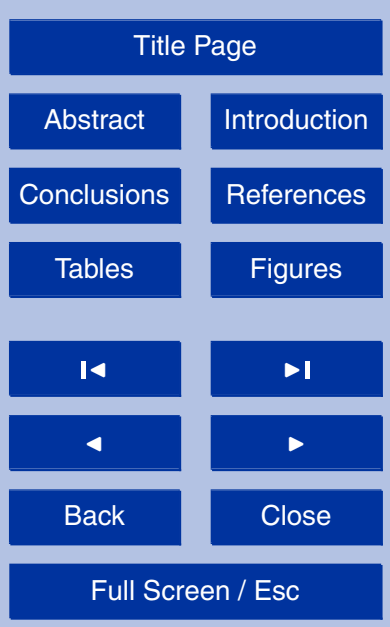

Printer-friendly Version

Interactive Discussion

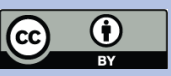




\section{Abstract}

Sea surface temperature (SST) is the main driver of simulated climate in coupled atmosphere-ocean general circulation models. A reliable reconstruction of past SST is necessary to simulate past climate realistically. We here present a novel method for 5 reconstructing SST on the basis of terrestrial Holocene palaeothermometer data such that a climate model is able to represent the climate mean state in the land temperature time series.

For our study, we use the Earth system model of intermediate complexity Planet Simulator (PlaSim). The land climate is represented by the high-resolution and long-term palaeothermometer time series from Lake Ammersee (Southern Germany), where the temperature is derived from the stable $\delta^{18} \mathrm{O}$ isotope in ostracod valves. To provide a climate simulation which reflects the proxy-derived climate during the Holocene, we (i) determine the sensitivities of the terrestrial PlaSim climate with respect to SST anomalies for present day conditions; (ii) define the inverse of these sensitivities to find the

15 SST conditions necessary for representing past land proxy climate; and (iii) reapply the climate model to this newly reconstructed SST. We iterate over steps (ii) and (iii) until the mean model and proxy climate converge.

We demonstrate the applicability of this new method to reconstruct past climate by comparing the simulated land temperatures to an independent (pollen derived) proxy data set of land temperatures for Europe. The implementation of a wider range of terrestrial palaeotemperature information from proxy archives analogous to our method will foreseeably yield better reconstructions of past SST. These can, for example, be used to overcome many models' difficulties with simulations extending to the time before $8500 \mathrm{yr}$ before present, when the North American (Laurentide) ice sheet caused a no-analogue climate.
ESDD

3, 149-200, 2012

Reconstruction of SST for terrestrial Holocene climate

K. Haberkorn et al.

Title Page

Abstract Introduction

Conclusions

Tables References

Figures

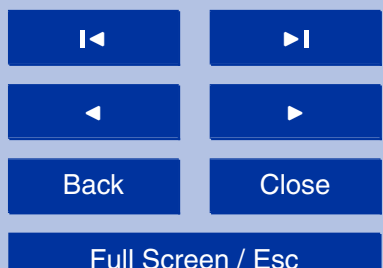

Full Screen / Esc

Printer-friendly Version

Interactive Discussion

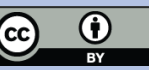




\section{Introduction}

Bringing together a climate simulated with general circulation models (GCMs) and the "real" climate - derived from observations - presents one of the largest challenges to the modelling community. For present day conditions, models are compared to either 5 direct observations or to reanalysis data (e.g. Kållberg et al., 2005); reanalysis data are treated as the best possible replication of the actual observations and are often used for validation of GCMs. This implies that GCMs should be able to reproduce the climate indicated by observational or reanalysis data - despite inherent deficiencies of individual models.

10 Besides the ability to simulate the present day climate with a GCM, the model should at the same time be capable to represent a climate that is different from current conditions; this task is unequally more complicated. Driven by reconstructions of climate forcing factors to account for long-term changes of the atmospheric state, the GCM can potentially produce diverging simulation results because of its unknown internal variability or general model limitations (Widmann et al., 2010).

For the comparison of simulated past climates, palaeoenvironmental data can be considered as "observations". These observations are indirect, or proximate, measurements of climatic variables; they are derived from theoretical or empirical relationships of the climate variable with a physical, chemical, or biological quantity in the environmental archive. Only rarely, the relationship is well enough understood to provide a quantitative measure of past temperature or precipitation from the proxy. Proxy data provide spatially incomplete information, and the data may be intermittent and poorly dated.

Uncertainties in model and proxy data make it difficult to find out whether the difinternal variability in both model and data (Goosse et al., 2010). It is an important and ongoing challenge to solve this problem of the inconsistency between proxies and models. One way to overcome this are data assimilation techniques (DA hereinafter).

ESDD

3, 149-200, 2012

Reconstruction of SST for terrestrial Holocene climate

K. Haberkorn et al.

Title Page

Abstract Introduction

Conclusions

Tables References Figures

14

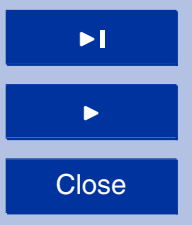

Back

Close

Full Screen / Esc

Printer-friendly Version

Interactive Discussion

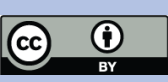


DA have been utilized for a long time in weather forecasting with the aim that the atmospheric states as given by the climate model - or more specifically the numerical weather prediction models (NWP) - agree with observations; in recent years, DA have been applied to model-proxy relationships in palaeoclimate simulations, with the prox5 ies serving as the observations. DA developed for the weather forecast cannot be transferred to palaeoclimate studies due to the strong differences between observations and proxy data (Widmann et al., 2010). Besides the problems of coarse spatial and temporal resolution, many proxies do not provide an instantaneous and periodic signal of the climate state but seasonal, annual, or longer-term means. In their study, 10 Widmann et al. (2010) present three DA which were developed for palaeoclimatic analyses and overcome the inherent difficulties of the proxy data. These DA have been used to predict the extratropical Northern Hemisphere climate over the last millennium through the use of a climate model and several proxy records. Although all three methods succeeded in closing the gap between the simulations and the reconstruc15 tions, there still remained uncertainties which were caused by the inconsistency of the different proxies, which showed partly opposing signals, and by the methodological difficulties of each DA and its inherent limitations. As Goosse et al. (2010) point out, it is very unlikely that it will ever be technically possible to bring the two components model climate and proxy data together, i.e. to find a system state that is compatible with the model physics and is at the same time consistent with the observational data: the more complex structure in the data cannot be represented by the simplified physics of the model (Goosse et al., 2010).

In the framework of DA, the inverse procedure can be equally used to bring together models and data. Both data assimilation and inverse modelling are closely related 25 and arise from a similar theoretical background. They both employ the basic principle of estimating the input from the knowledge of the output or target state (Wu et al., 2007; Widmann et al., 2010; Guiot et al., 2000, 2009). Different, mainly statistical, approaches to the inversion problem have been used in diverse applications: for example, they have been used for palaeovegetation modelling (Guiot et al., 2000, 2009;
ESDD

3, 149-200, 2012

\section{Reconstruction of SST for terrestrial Holocene climate}

K. Haberkorn et al.

Title Page

Abstract Introduction

Conclusions

Tables References Figures

14

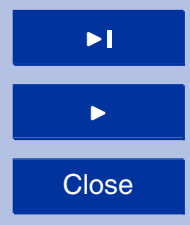

Back

Close

Printer-friendly Version

Interactive Discussion 
Wu et al., 2007; Garreta et al., 2010), where modelled and reconstructed vegetation (through pollen assemblages) are compared to deduce the climatic conditions which correspond best to the reconstructed vegetation. Other examples of applications of inverse methods are the identification of atmospheric $\mathrm{CO}_{2}$-patterns (e.g. Bousquet et al., 5 1999a,b; Göckede et al., 2010a,b), or an analysis of the deep ocean circulation during the past, based on the ${ }^{231} \mathrm{~Pa} /{ }^{230}$ Th-ratio in ocean sediments (Burke et al., 2011); this ratio can serve as a proxy for the overturning circulation. In their study, Burke et al. (2011) investigate the spatially only limited occurrence of ${ }^{231} \mathrm{~Pa} /{ }^{230} \mathrm{Th}$ using an inverse approach to test potential consistencies with the estimated ocean circulation of modern 10 times.

Our study follows the inverse modelling idea; unlike other studies, it is not based on an analytical inversion but on an iterative and dynamical procedure: we gradually proceed to converge the proxy climate with the GCM, with the focus on introducing a method to adjust a specific climate model to a specific set of proxies. We compare 15 simple maps of both model and proxy, considering that, in any case, there will be a more or less strong difference between them.

We do not intend to investigate the real Holocene SST pattern any further, which has been identified and analyzed in many studies so far, such as Kim et al. (2004), Rimbu et al. $(2003,2004)$, Berner et al. (2008), or Grosfeld et al. (2008). Nor do we aim at making qualitative contributions to the question of how the SST looked like during that time, nor do we analyze the robustness of either the proxy or the climate model, as done by, for example, Wirtz et al. (2010), Mayewski et al. (2004), or Wanner et al. (2008).

Our intention is the more technical approach of the model adjustment to a given dataset rather than a profound analysis of the differences in order to make a statement of how the climate was during the past. We restrict ourselves to putting forward this new method, applied for a specific GCM; thus, the reconstructed SST is also GCMdependent. A further comparison to SST-proxies should not be neglected, but goes beyond the scope of this study. We argue that the methodology applied here can be easily transferred to any other GCM.
ESDD

3, 149-200, 2012

Reconstruction of

SST for terrestrial Holocene climate

K. Haberkorn et al.

Title Page

Abstract Introduction

Conclusions

Tables References Figures 14

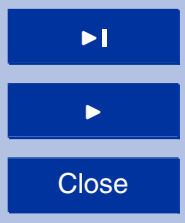

Back

Close

Printer-friendly Version

Interactive Discussion 
The larger framework in which our work is embedded, aims at the simulation of the climatic conditions which led to the settlement of early humans during the Holocene and, as a second step, to analyze their influence on the climate. Recent analyses of early Holocene land use and climate impact identified Europe as one of the key 5 regions for human-climate interactions (Olofsson and Hickler, 2008; Lemmen, 2009; Kaplan et al., 2011). Also, the validation of simulated human-climate interactions is most feasible for Europe from archaeology (e.g. Lemmen et al., 2011) and palaeobotany (e.g. Gaillard et al., 2010). Thus, the main region of interest of this study is the European sector with a focus on European temperature changes, given by selected 10 European proxies.

The outline of this paper is as follows: after briefly describing the Earth system model Planet Simulator, the experimental setup and the proxy data, we introduce our iterative reconstruction method; we show the results of the reconstruction of SST for selected time slices during the Holocene, at present day, 6000 and $9000 \mathrm{yr}$ ago. We further look

at the outcome of the reconstruction for the whole region of Europe, which then leads to the discussion and a critical assessment of this new reconstruction method, mainly with regard to its general usefulness and benefits but also its limitations. We conclude our study with an outlook on potential refinements of this procedure.

\section{Data and methodology}

The simulations are carried out with the Planet Simulator (PlaSim), an Earth System model of intermediate complexity (EMIC) ${ }^{1}$. Its dynamical core for the atmosphere is adopted from the Portable University Model of the Atmosphere (PUMA). The atmospheric dynamics uses the primitive equations for vorticity, divergence, temperature

${ }^{1}$ PlaSim is freely available software, download from http://www.mi.uni-hamburg.de/plasim

\section{ESDD}

3, 149-200, 2012

Reconstruction of SST for terrestrial Holocene climate

K. Haberkorn et al.

\section{Title Page}

Abstract Introduction

Conclusions References

Tables Figures

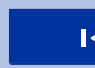

14 $\rightarrow 1$

4

Back

$\checkmark$

Close

Full Screen / Esc

Printer-friendly Version

Interactive Discussion

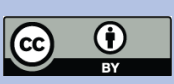


and the logarithm of surface pressure. These equations describe the momentum, energy and mass balance and are solved using the spectral transform method (Eliasen et al., 1970; Orszag, 1970). Unresolved processes are implemented using parameterizations for the long- (Sasamori, 1968) and shortwave (Lacis and Hansen, 1974) 5 radiation, moist (Kuo, 1965, 1974) and dry convection, large-scale precipitation, interactive clouds (Stephens, 1978; Stephens et al., 1984; Slingo and Slingo, 1991), boundary layer fluxes of latent and sensible heat and vertical and horizontal diffusion (Louis, 1979; Louis et al., 1982; Laursen and Eliasen, 1989; Roeckner et al., 1992). Over land, soil temperature and hydrology are simulated by a five layer heat diffusion and a 10 bucket model, respectively. A more comprehensive description of the Planet Simulator can be found in Lunkeit et al. (2010). A simulation of present day climate (Haberkorn et al., 2009) with prescribed SST and sea ice based on the climatological annual cycle taken from the Atmospheric Model Intercomparison Project (AMIP II, Gates, 1992 and Taylor et al., 2000) showed good agreement with the reanalysis data ERA-40 (Euro15 pean Center for Medium Range Weather Forecast reanalysis, Uppala et al., 2005 and Kållberg et al., 2005) in terms of spatial distributions of the first and second moments of the climate variables. The global energetics appear to be well represented, too. Major differences are apparent in the polar regions, where the model exhibits a cold bias and a too strong zonality of the stationary wave pattern.

PlaSim has been used in a wide range of fields; due to its medium complexity and associated less extensive computing requirements, it is especially suitable for palaeoclimate research. The modular structure of the model is beneficial as it easily enables a problem-dependent configuration. These are, for example, hysteresis experiments on a Snowball Earth (Lucarini et al., 2010) with regard to thermodynamic aspects and the identification of potential tipping points in the system. Another application of PlaSim is the work by Fraedrich and Lunkeit (2008) who investigated the entropy balance of the Earth system. Other studies - by Fraedrich et al. (2005) or Dekker et al. (2010) - analyzed the interactions between atmosphere and biosphere under extreme vegetation scenarios. PlaSim can couple to different ocean models besides
ESDD

3, 149-200, 2012

\section{Reconstruction of SST for terrestrial Holocene climate}

K. Haberkorn et al.

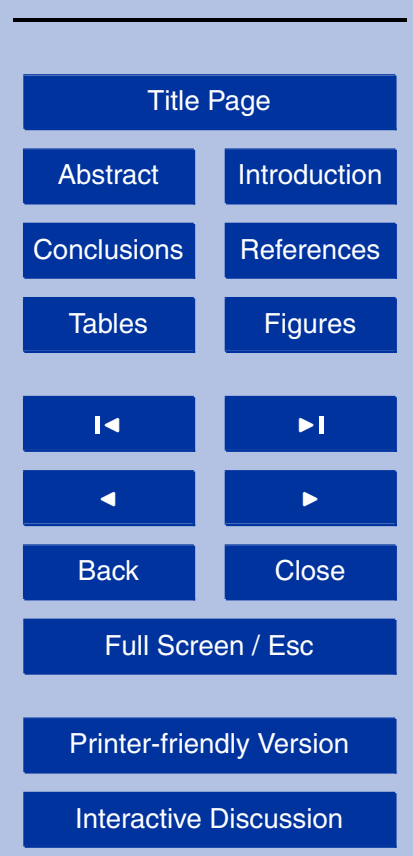


using climatological (fixed) SST. These ocean models can be a mixed-layer ocean or the large-scale geostrophic ocean (LSG, Maier-Reimer et al., 1993). In the study by Schmittner et al. (2011), PlaSim is used together with the University of Victoria model (UVic), combining the atmospheric circulation of PlaSim with the ocean, sea ice, 5 land surface and ocean biogeochemical components of UVic to form the new oceanatmosphere Oregon State University-University of Victoria model (OSUVic) to investigate the impact of mountains and ice sheets on the large-scale circulation. Compared to other EMICs in the scientific community, such as CLIMBER, ECBILT-CLIO, or others listed in the paper by Claussen et al. (2002), PlaSim can, from the atmospheric point 10 of view, be regarded as a more complex, i.e. full, GCM: all atmospheric processes are included, but with the limitation of less sophisticated parameterizations. Instead of the coarser atmosphere, other EMICs are composed of, for example, a much more complex ocean model or include other subcomponents like a carbon cycle model. Besides their individual differences, all EMICs have in common that they are suitable for 15 long-term and problem-specific experiments.

\subsection{Palaeoenvironmental data}

For comparison, we rely on palaeoclimate proxy time series from the long-term high resolution time series compilation by Wirtz et al. (2010). They assembled a total of 124 climate proxies at 103 globally distributed sites from existing literature. All time se20 ries span at least $4000 \mathrm{yr}$, and most have a resolution of $200 \mathrm{yr}$ or better. In their study, Wirtz et al. (2010) analyzed the palaeoclimate records with regard to their statistical behavior, i.e. mainly the variability on different time scales. They found evidence for a variability change in the mid-Holocene, around $5000 \mathrm{yr}$ before present (BP, relative to 1950), and they identified geographically organized clusters of each six to ten proxies 25 which exhibit identical variability trends. This is interesting because diverse climatological variables are forming these clusters so one would have expected a different spectral behavior. These clusters are composed on a subcontinental scale with a diameter of roughly $3000 \mathrm{~km}$. The statistical similarity is significant over a relatively large area and

\section{ESDD}

3, 149-200, 2012

\section{Reconstruction of SST for terrestrial Holocene climate}

K. Haberkorn et al.

Title Page

Abstract Introduction

Conclusions

Tables References Figures

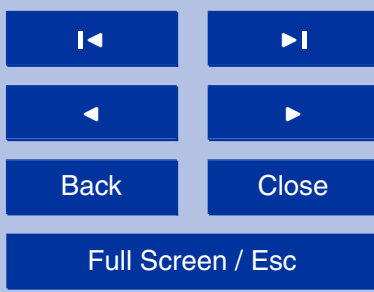

Printer-friendly Version

Interactive Discussion

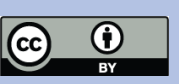


not only for one single proxy (Wirtz et al., 2010). This result is relevant for the choice of our proxy with regard to its representativeness as a valuable indicator of European climate change over the Holocene (see Sect. ??). As, for our studies, we want to directly relate the climate model to climate proxy data, only those data are chosen which give 5 quantitative information on the climatological variables surface temperature and annual precipitation, for example mid- and high-latitude palaeothermometer proxies based on $\delta^{18} \mathrm{O}$.

For testing our SST reconstruction method, we initially confine to one specific proxy time series, which has been obtained from Lake Ammersee in southern Germany at 10 $48^{\circ} \mathrm{N}$ and $11^{\circ} \mathrm{E}$. From $80 \mathrm{~m}$ water depth, von Grafenstein et al. (1998) analyzed the oxygen isotope ratio $\left(\delta^{18} \mathrm{O}\right)$ of ostracod valves, which reflects the temporal variation in local precipitation; this, in turn, is controlled by mean annual air temperature (von Grafenstein et al., 1998). The original data curve of the Ammersee proxy is built on the raw data (von Grafenstein et al., 2003) of the $\delta^{18}$ O-values for the whole Holocene, i.e. the period from 0 to 12 kiloyear (kyr) BP, and is presented in Fig. 1.

The oxygen isotope fractionation $\left(\delta^{18} \mathrm{O}\right)$ as the difference of the sample ratio of ${ }^{18} \mathrm{O}$ to ${ }^{16} \mathrm{O}$ relative to the PDB standard (von Grafenstein et al., 1998) is a well-established indicator of climate changes. It is affected by changes in the local water balance (i.e. balance of precipitation, evaporation and runoff) with higher amounts of evaporation leading to lower ${ }^{16} \mathrm{O}$, leaving ${ }^{18} \mathrm{O}$ unaffected, and hence to a higher $\delta^{18} \mathrm{O}$-value. The strong sensitivity of $\delta^{18} \mathrm{O}$ to the water balance implies on the one hand a strong dependency on the geographic location and the environmental settings. On the other hand, the fractionation is also highly temperature-dependent because the water balance is strongly affected by the mean air temperature. Higher evaporation occurs during colder periods, whereas warmer periods are influencing the heavier ${ }^{18} \mathrm{O}$ with the result of a lower $\delta^{18} \mathrm{O}$ (Fig. 1).
ESDD

3, 149-200, 2012

\section{Reconstruction of SST for terrestrial Holocene climate}

K. Haberkorn et al.

Title Page

Abstract Introduction

Conclusions References

Tables Figures
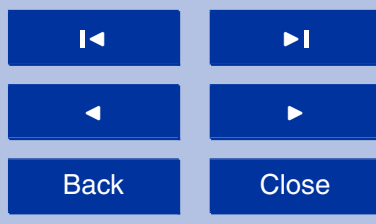

Full Screen / Esc

Printer-friendly Version

Interactive Discussion

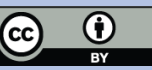


The seeming discrepancy between a proxy reflecting precipitation variations and its interpretation with regard to temperature changes has been rectified by, for example, Dansgaard (1964) or Rozanski et al. (1992), who demonstrated a strong relationship between annual mean precipitation and annual mean surface air temperature. Rozan5 ski et al. (1992) found a close correlation between both climatic variables for different regions around the globe, which indicates the suitability of these isotopes as a palaeoclimatic indicator. Besides general uncertainties affecting all proxies - temporal and spatial resolution - the difficulty of a correct dating (Alley et al., 1997; Wiersma and Renssen, 2006) is important. For the Ammersee proxy, the chronology of the core has 10 been tested using two independent age models: both show a strong similarity and thus reliability (von Grafenstein et al., 1998).

The oxygen isotope fractionation in the Ammersee proxy in particular has been proven a very sensitive archive for high-resolution palaeotemperature reconstructions (von Grafenstein et al., 1998, 1999). Following these studies, the responses of a varved 15 sediment record in the Ammersee have been investigated with regard to changes in the hydrological cycle by Czymzik et al. (2010): the authors reconstructed a flood time series from this sediment for the last half millennium taking into account that the detrital layers in those varved lake sediments are caused by flood-triggered fluxes from the nearby Ammer River (Alefs, 1997; Czymzik et al., 2010). Czymzik et al. (2010) identified a clear seasonal signal of flood-induced detrital material in the annual sedimentation rates.

Focussing on the palaeotemperature reconstructions, von Grafenstein et al. (1998) identified a signal pointing to the 8.2 kyr event (Alley et al., 1997; Alley and Ágústsdóttir, 2005), during which strong freshwater pulses (affecting the $\delta^{18}$ O-ratio) were triggered by the final melting stages of the Laurentide ice shield, and which strongly influenced the North Atlantic thermohaline circulation by affecting the North Atlantic deep water formation. These freshwater pulses impeded the northward heat transport (Rohling et al., 2002) and initiated cooler and drier conditions lasting about $300 \mathrm{yr}$. Although the causal relation between the proxy signal in the Ammersee and the freshwater
ESDD

3, 149-200, 2012

\section{Reconstruction of \\ SST for terrestrial Holocene climate}

K. Haberkorn et al.

Title Page

Abstract

Introduction

Conclusions

Tables

References

Figures

14

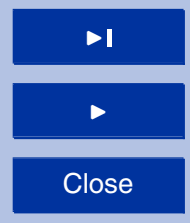

Back

Close

Printer-friendly Version

Interactive Discussion 
discharge is not fully resolved (von Grafenstein et al., 1998), a close relationship is strongly hypothesized. Due to the very complex structure of this cooling event, only few modelling studies have been performed, such as those by Ágústsdóttir (1998), Renssen et al. (2001, 2002) or Bauer and Ganopolski (2004). Wiersma and Renssen 5 (2006) compared model output with proxy data for the $8.2 \mathrm{kyr}$ event and found a strong model-data agreement which confirmed the assumed freshwater forcing mechanism of the event. Consistent with the problems of models to simulate this event, it is also not easily identified by the proxy data in the affected regions. Whereas for the models the problem is mostly due to simulating the forcing correctly, several obstacles come 10 along with the proxy data, including the chronology uncertainty. This uncertainty becomes even more significant when a short duration event is of interest, like the $8.2 \mathrm{kyr}$ event: the brevity of the event $(\approx 300 \mathrm{yr})$ complicates the selection of proxies further as many sites do not have a sufficient temporal resolution to find a signal of this temporal span (Alley and Ágústsdóttir, 2005). The $8.2 \mathrm{kyr}$ signal is, however, registered in several high-resolution proxy data around the North Atlantic (Renssen et al., 2001), such as in ice cores from Greenland (Alley et al., 1997; Blunier et al., 1995), ocean or lake sediments of the North Atlantic (Bond et al., 1997) or the ones cited in the study by Wiersma and Renssen (2006), tree ring records from northern and southern Germany (Klitgaard-Kristensen et al., 1998) and the cores of lake Ammersee in southern Germany (von Grafenstein et al., 1998). Summing up, because of the consistency and the contemporaneous signal also in other studies - even on temporally very small scales as for the $8.2 \mathrm{kyr}$ event - the $\delta^{18} \mathrm{O}$-record of the Ammersee proxy seems to be a reliable and significant climate indicator, providing quantitative material for palaeoclimatic analyses.

\subsection{Experimental design}

We use PlaSim in T21 horizontal resolution $\left(\approx 5.6^{\circ} \times 5.6^{\circ}\right.$ on the corresponding Gaussian grid) with ten not equally spaced sigma levels in the vertical. As a reference experiment, we choose a Holocene climate simulation with prescribed SST based on
ESDD

3, 149-200, 2012

\section{Reconstruction of SST for terrestrial Holocene climate}

K. Haberkorn et al.

Title Page

Abstract Introduction Conclusions

Tables References Figures

14

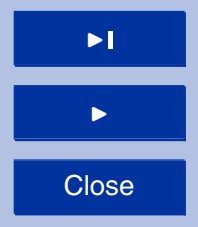

Back

Close

Full Screen / Esc

Printer-friendly Version

Interactive Discussion

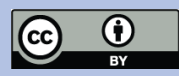


the climatological annual cycle. Sea ice and other subsystems are prescribed by their climatological annual means. This transient reference experiment is forced by longterm orbital (Berger, 1978b) and greenhouse gas (GHG) forcing (from Taylor Dome, Indermühle et al., 1999); all forcings are shown in Fig. 2. The model is used with a 5 calendar of 360 days per year, i.e. 30 days per month. The performance of this model setup, i.e. with the climatological cycle of SST and sea ice, has previously been assessed by Haberkorn et al. (2009) for present day conditions. The reference simulation yields a time series of SST for the Holocene which is characterized by the long-term changes in orbital and GHG forcing. The main deficiency of the ocean with climatolog10 ical SST is the lack of internal variability which occurs at all time scales up to several millennia. This low frequent variability cannot be recovered by this ocean representation because all oceanic responses and potential feedbacks are strongly dampened when the SST are predefined and not subject to change. Hence, the ocean is unable to vary which impedes the formation of any kind of internal (oceanic) variability. Proxy data may therefore stand in for providing information about the variability patterns.

\subsection{Model-data differences}

The reconstructed time series of the Ammersee proxy for the period 0 to $11 \mathrm{kyr} B \mathrm{P}$ is presented in Fig. 3 together with the time series taken from the transient Holocene reference simulation with PlaSim, where we selected the corresponding grid points 20 of the Ammersee proxy ( $48^{\circ} \mathrm{N}$ and $\left.11^{\circ} \mathrm{E}\right)$. The proxy shows the commonly observed temperature trend for the Holocene with an early Holocene cooling, followed by a midHolocene warming (climate optimum) and again a cooling from around $3000 \mathrm{yr} \mathrm{BP}$ until the preindustrial period (Wanner et al., 2008). PlaSim instead shows a smooth warming trend until the late Holocene, but no comparably remarkable trend during the mid-

\section{ESDD}

3, 149-200, 2012

\section{Reconstruction of SST for terrestrial Holocene climate}

K. Haberkorn et al.

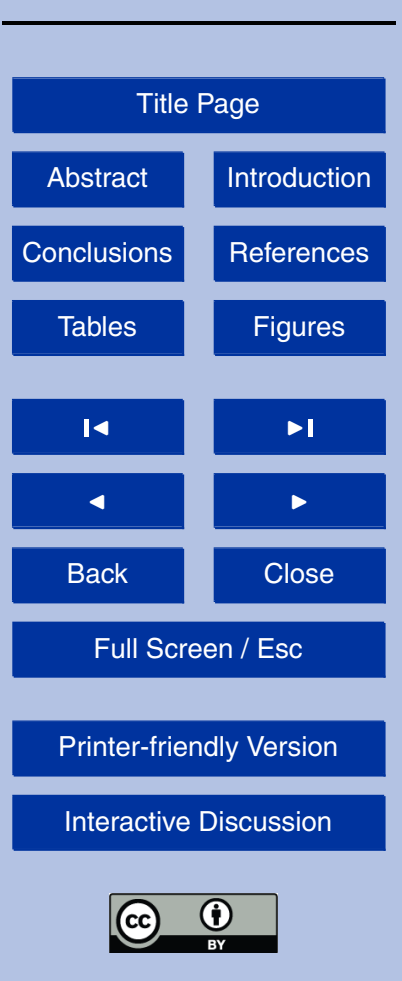


several longer periods during the mid-Holocene, PlaSim is slightly colder. During the early and late Holocene there is a tendency of a warmer model climate compared to the proxy.

\subsection{Methodology}

5 We employ an iterative assimilation procedure to incorporate a proxy time series into a GCM to initialize new palaeoclimate simulations. Our approach follows the assumption of a distinct dependency between an imposed forcing on the climate system and its response with the result that any kind of external perturbation to the climate system will lead to a change in climate. This response in terms of global mean temperature changes is then related to the global mean radiative forcing (Boer and $\mathrm{Yu}, 2003$ ). The constant of proportionality which relates the forcing to the changes in climate is equivalent to a measure of the strength of the feedback processes and of the sensitivity of the climate system (Boer and Yu, 2003; Gregory et al., 2004; Pachauri and Reisinger, 2007). It can be determined in climate change simulations with a GCM and, as Boer and $\mathrm{Yu}(2003)$ point out, is approximately constant and hence independent of both climate state and forcing (Boer and Yu, 2003; Gregory et al., 2004). Consequently, each GCM and the real climate system have different response parameters (sensitivities). Therefore, this concept is commonly used in analyses of climate change when different models and/or forcings are intercompared (Gregory et al., 2004). When the climate ing - not only radiative - in a straightforward way, which is also shown by Good et al. (2011) who used this theory to reconstruct climate model projections. As Wirtz et al. (2010) point out in their proxy analysis, variations in one variable like SST may have a strong influence on another variable in close vicinity, and which can be, for example,

surface air temperature. This statistically determined spatial relationship is also shown by Wilson et al. (2010) who identified a strong correlation between tree ring series in the western parts of South America and SST in the tropical Pacific, which they used for reconstructing the El Niño-Southern Oscillation (ENSO) during the past century.
ESDD

3, 149-200, 2012

Reconstruction of SST for terrestrial Holocene climate

K. Haberkorn et al.

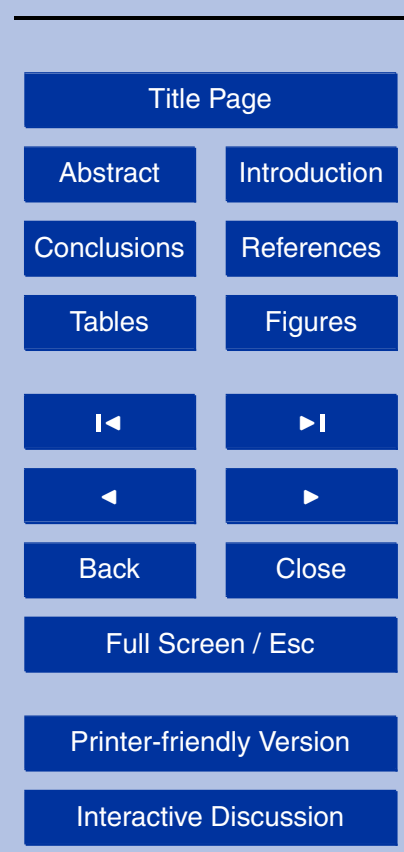

Interactive Discussion

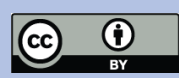


These above studies support the idea of directly linking SST anomalies to modifications of adjacent land temperatures. Following this theory, our approach is based on the assumption of a linear sensitivity relationship between the SST and the adjacent land climate. This assumed linearity is also emphasized by Ljungqvist et al. (2012) in 5 their analysis of Northern Hemisphere temperature variability over the last century. The SST serves as an essential and common boundary condition in a model and leads to a specific (and, at the beginning, unknown) mean climate as the direct linear response of the SST forcing. We focus only on SST; all other boundary conditions (e.g. glacier mask or vegetation-related parameters like albedo or roughness length) or external 10 forcings (e.g. orbital and GHG) are not considered in this context. This standard procedure is limited to present day conditions or at least to those circumstances where the boundary conditions are completely known - apart from their general uncertainty. The linear relationship can be expressed as

$\bar{T}=\lambda \times \overline{\mathrm{SST}}$,

15 where $\bar{T}$ and $\overline{\text { SST }}$ are the annual mean climate and SST respectively. The coefficient $\lambda$ is calculated from Eq. (1) and serves as the correcting (sensitivity) term between the global mean climate and the global mean SST, determining the strength of the response. If not stated otherwise, in the following all parameters such as $\bar{T}, \lambda$ and $\overline{\text { SST }}$ are specified to their annual values. This approach cannot be easily transferred to palaeoclimatic studies, where both quantities are unknown: we neither know the mean climate nor, and even less, the oceanic conditions at a certain time period in the past. Here, the proxy data become important by serving as a direct indicator of the past mean climate in the influence region of the proxy. This implies a switch from the global to the regional perspective - Europe in our case. The various SST proxies existing in the literature are not taken into account in this study. The main reason is the inherent uncertainty of the SST proxies. According to Berner et al. (2008) or Leduc et al. (2010), the existing SST proxies give different (partly even opposing) results, depending on the kind of proxies used, e.g. alkenone unsaturation or $\mathrm{Mg} / \mathrm{Ca}$ ratio. This complicates an 162
ESDD

3, 149-200, 2012

\section{Reconstruction of SST for terrestrial Holocene climate}

K. Haberkorn et al.
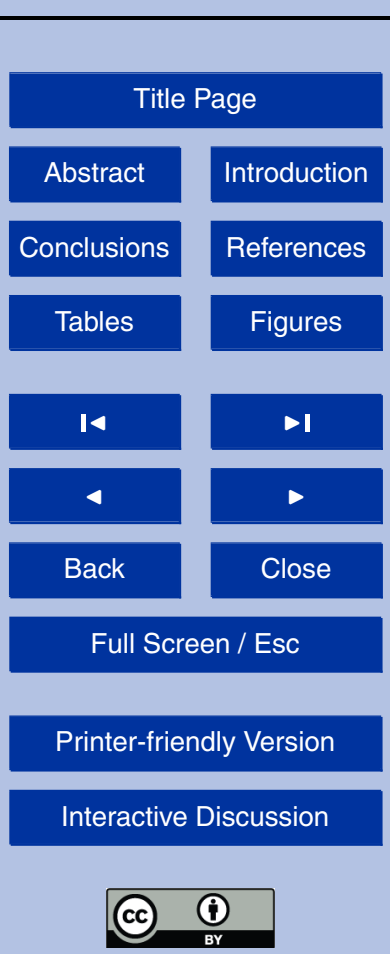
intercomparison of different proxy types (Kim et al., 2004; Weldeab et al., 2007; Wirtz et al., 2010) and, even more, a comparison to climate model output. Studies which have made assumptions about specific features like the climate (Rimbu et al., 2004; Lorenz et al., 2006) or SST variability (Kim et al., 2004) during the Holocene, have only 5 a single SST proxy type. Our aim is to overcome the apparent discrepancy between the still unknown oceanic conditions and the known mean climate given by the proxies. This implies that the model's boundary conditions (SST) have to be adjusted to a given climate instead of setting up a climate simulation where known boundary conditions are leading to an unknown mean climate. The adjustment of the SST is made possible 10 by using the sensitivity which is calculated in Eq. (1). This is equivalent to a switch from forward to inverse modelling, i.e. to estimate the input from the known output or target state (Wu et al., 2007; Widmann et al., 2010; Guiot et al., 2000, 2009). Through this, we are able to derive the SST which are appropriate to simulate a predefined climate. For this purpose, Eq. (1) needs to be slightly modified, to include the deviations between 15

$\Delta T=\lambda \times \Delta \mathrm{SST}$,

where $\Delta T$ is defined as the difference between the annual mean model climate $\bar{T}$ for Europe and the proxy climate $T_{\mathrm{P}}$, i.e. $\bar{T}-T_{\mathrm{P}}$, and $\Delta \mathrm{SST}$ as the corresponding annual mean SST anomalies.

Our method can be roughly divided into three stages (i)-(iii) and three substeps (a)(c) which are explained below. The relationship between SST and $T$ is shown in Fig. 4. To give the proxy (or observation)-derived land climate, the SST is modified with the sensitivity $\lambda$ which is determined below.
ESDD

3, 149-200, 2012

Reconstruction of SST for terrestrial Holocene climate

K. Haberkorn et al.

Title Page

Abstract Introduction

Conclusions

Tables References Figures

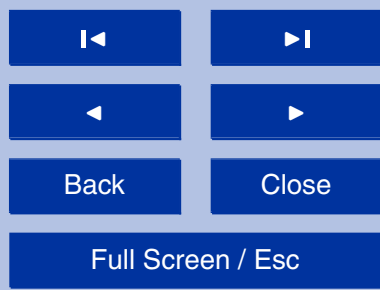

Printer-friendly Version

Interactive Discussion

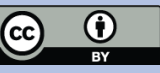


(i) Establish the sensitivity $\lambda$;

(a) define a proxy (target) region where proxies are available and represent climate during the period of interest;

ESDD

3, 149-200, 2012

(b) choose the source region in the ocean which is most relevant for the target region;

(c) define $\lambda$ as the sensitivity of the model climate $\bar{T}$ in the target region to a change of SST in the source region (Eq. 2);

(ii) determine source SST conditions necessary for the adjustment to the target climate by using the inverse of this sensitivity, or feedback parameter $\left(\lambda^{-1}\right.$, Boer and Yu, 2003);

(iii) reapply the climate model with the reconstructed source SST.

\section{(i) Calculation of sensitivity}

For the European focus region (substep (a)), the oceanic source region with the strongest influence is detected by a set of sensitivity studies. These are carried out 15 under present day conditions, and assuming that the interaction between the climate subsystems remains the same through time. This is consistent with assumptions made in other studies (Wu et al., 2007; Guiot et al., 2009; Sundqvist et al., 2010; Laepple and Lohmann, 2009; Wilson et al., 2010; Ljungqvist et al., 2012) on palaeoclimatic reconstructions and an essential prerequisite for the overall possibility of reconstructing past climates. In these first sensitivity experiments, we forced different oceanic regions with arbitrary (but known) SST anomalies and subsequently calculated the responses of the land temperatures in the adjacent regions - relative to a control simulation without SST forcing. We found that for a proxy in central Europe, the source region in the ocean with the strongest influence on the European land climate is the North Atlantic $\left(0^{\circ}-60^{\circ} \mathrm{N}\right.$, 25 Fig. 4). Our findings are in line with the study by Rodwell et al. (1999), where the authors quantified the oceanic role in the forcing of the climate of the North Atlantic and

\section{Reconstruction of SST for terrestrial Holocene climate}

K. Haberkorn et al.

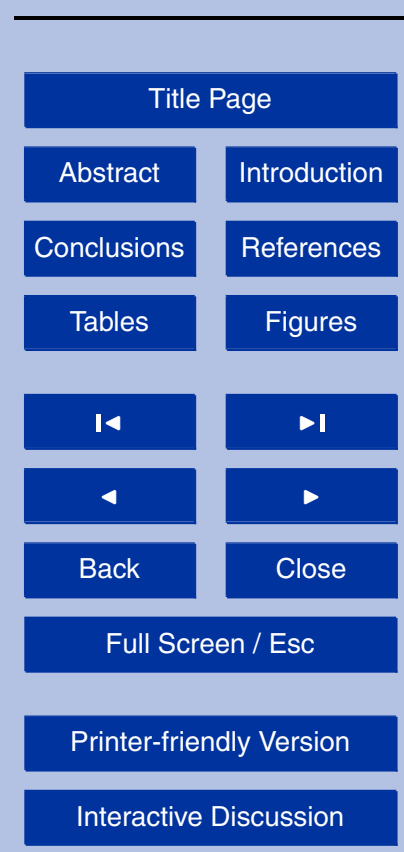

Interactive Discussion

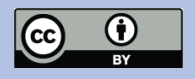


Europe. They revealed that SST anomalies and the strength of the North Atlantic Oscillation (NAO) are strongly related and that the oceanic information is exchanged with the atmosphere in terms of hydrological processes directly influencing the climatic conditions in Europe. Other studies, for example by Sutton and Hodson $(2003,2005)$, by 5 Löptien and Ruprecht (2005), or by Grosfeld et al. (2008), also emphasize the special role of the North Atlantic and the NAO for European weather and climate. After having identified the oceanic region (substep (b)), the sensitivity $\lambda$ needs to be determined (substep (c)). For this, we apply Eq. (2) to a simulation where we modified the SST in the North Atlantic $(\triangle S S T)$ and subsequently calculated the responding temperature 10 change over Europe $(\Delta T)$.

\section{(ii) Determination of the source SST conditions}

We now determine the SST conditions which are appropriate to simulate a predefined climate; this implies the switch to the inverse modelling procedure. We assume an arbitrary annual temperature change over Europe ( $\Delta T$, this will be given by the proxy 15 climate in a later stage) and adapt Eq. (2) using the inverse of the sensitivity $\lambda$ to determine the corresponding annual SST anomalies ( $\Delta S S T)$. As an alternative solution, Eq. (2) is modified to consider seasonally varying sensitivities. Taking into account the seasonal signal for the sensitivities in contrast to the annual mean temperature changes, which build the basis for the comparison of model and proxy data, may be 20 inconsistent but becomes more comprehensible when considering the different thermal inertia of the ocean influencing the land temperature. Although we do not use a free ocean in our studies, the annual cycle is included in the climatological SST. Our seasonal modification is corroborated by Laepple and Lohmann (2009), who presented a statistical model to simulate the palaeoclimatic temperature evolution. Their is governed by the seasonally varying insolation. Assuming an identical temperature response, this relation is then applied to palaeoclimate timescales. Mainly with regard to the Holocene insolation distribution, our procedure with the seasonal splitting

ESDD

3, 149-200, 2012

Reconstruction of SST for terrestrial Holocene climate

K. Haberkorn et al.

Title Page

Abstract Introduction

Conclusions References

Tables Figures
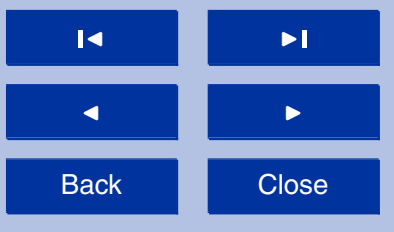

Full Screen / Esc

Printer-friendly Version

Interactive Discussion

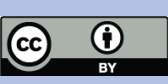


is therefore consistent. This distribution changes on geological time scales (i.e. for glacials and interglacials) due to variations in the Earth's orbit around the sun. This led to more (less) incoming solar radiation during summer (winter) in the mid-Holocene (cf. Fig. 2), which then caused an intensification of the seasonal cycle. Assigned to an 5 annual signal, these changes in insolation (and the respective changes in e.g. temperature) are small but the annual temperature change is indeed influenced by the seasonal variations (Fischer and Jungclaus, 2010). Apart from these modelling studies, our approach is further underpinned by proxy analyses, such as the work of Davis et al. (2003), who clearly identified seasonal differences in Holocene temperature trends in 10 their pollen climate reconstruction. In their investigations of SST proxy records, both Leduc et al. (2010) and Schneider et al. (2010) revealed a seasonal signal which is induced by the changing orbital forcing throughout the Holocene.

A seasonal modification of Eq. (2) is

$\Delta T_{\text {ann }}=\overline{\lambda_{\mathrm{s}} \times \Delta \mathrm{SST}_{\mathrm{s}}}$,

15 where the increment $S$ denotes the consideration of the seasonal signal, i.e. the respective seasonal sensitivity and SST, and

$\lambda_{\text {ann }} \times \Delta \mathrm{SST}_{\mathrm{ann}}=\overline{\lambda_{\mathrm{s}} \times \Delta \mathrm{SST}_{\mathrm{s}}}$.

The linearity assumption on $\lambda_{\text {ann }}$ implies that the annual sensitivity is the mean over the four seasons, i.e.

$20 \quad \lambda_{\mathrm{ann}}=1 / 4 \times \overline{\lambda_{\mathrm{s}}}=1 / 4 \times\left(\lambda_{\mathrm{DJF}}+\lambda_{\mathrm{MAM}}+\lambda_{\mathrm{JJA}}+\lambda_{\mathrm{SON}}\right)$.

We find that the oceanic influence is largest in winter and summer and therefore define the sensitivities of MAM and SON to their annual values, i.e. $\lambda_{\text {MAM }}=\lambda_{\text {SON }}=\lambda_{\text {ann }}$ (Tab. 1). Only $\lambda_{\text {DJF }}$ and $\lambda_{\text {JJA }}$ must be adjusted so that Eq. (5) is fulfilled. This yields $\lambda_{\text {DJF }}>\lambda_{\text {MAM }}=\lambda_{\text {SON }}>\lambda_{\text {JJA }}$.

$25 \quad$ Using these annual and seasonal sensitivities, the SST are determined on the basis of the assumed annual temperature change over Europe $\left(\Delta T_{\text {ann }}\right)$ and are subsequently 166
ESDD

3, 149-200, 2012

Reconstruction of

SST for terrestrial Holocene climate

K. Haberkorn et al.

Title Page

Abstract

Introduction

Conclusions

References

Tables

Figures

14

DI

4

Back

Close

Full Screen / Esc

Printer-friendly Version

Interactive Discussion

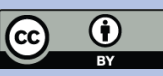


used to initialize a new set of sensitivity experiments (stage (iii)) of which the most relevant results are listed in Table 1. The three columns show the assumed temperature change $\Delta T_{\text {ann }}$ of $+1.5^{\circ} \mathrm{C}$, the corresponding (annual and seasonal) SST anomalies $\Delta S S T$ and the simulated annual temperature change $\Delta T_{\text {sim, ann }}$. It turns out that the an5 nual sensitivity $\lambda_{\text {ann }}$ and hence the annual SST anomalies $\Delta S S T_{\text {ann }}$ are not appropriate to resimulate the assumed mean climate change: the constant annual SST anomaly of $+2.71^{\circ} \mathrm{C}$ leads to a higher than expected simulated temperature change $\Delta T_{\text {sim,ann }}$ of $1.62^{\circ} \mathrm{C}$ (first line). In the second line, the seasonally differentiated SST are shown. As the simulated temperature anomaly fits well to the assumed temperature change of $10+1.5^{\circ} \mathrm{C}$, it turns out that a consideration of the seasonal cycle of the SST leads to a strongly improved result. These seasonal sensitivities, given in the last line, will now remain constant for all subsequent experiments, which is consistent with the remarks in Sect. 2.5.

Our approach is illustrated and summed up in Fig. 5: starting with the default (stan15 dard) set of SST from the AMIP climatology, which is used for a first simulation, a mean model climate, i.e. the mean temperature, calculated for a certain period of time and for a specific region - Europe in our case, is obtained. This simulated mean is then compared to the assumed climate mean, or equally the climate mean which is predetermined by the proxies. This comparison leads to the $\Delta T_{\text {ann }}$, defined as the anomaly

20 between the annual mean model climate $\bar{T}$ and the proxy climate $T_{\mathrm{P}}$. At this stage, the splitting to the seasonal sensitivities is taking place, on which we confine in this diagram, as they are subsequently used to adjust the SST through Eq. (3), i.e. higher SST if $\Delta T$ is $<0$ (PlaSim is colder than the proxy), or vice versa. The seasonal SST anomalies are then used to modulate the initial set of SST and to start a subsequent simulation which will then give a new mean model climate which is then again compared to the proxies. This procedure leads to a stepwise determination of SST necessary for reconstructing the proxy climate. This iterative scheme can thus be equally applied to our preliminary studies finding out the final seasonal sensitivies as well as to the process of periodically reconstructing the proxy climate over a longer time period, e.g. the whole
ESDD

3, 149-200, 2012

\section{Reconstruction of SST for terrestrial Holocene climate}

K. Haberkorn et al.

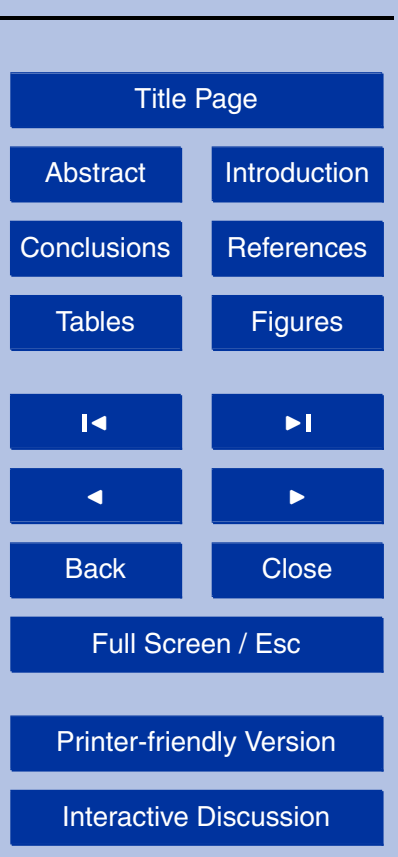


Holocene. The most important and recurrent part of this procedure is highlighted in bold. Wu et al. (2007) and Guiot et al. (2000) use a similar schematic representation of their inverse vegetation modelling approach. The included transfer matrix accounts for the use of raw data from the vegetation proxies to be converted into the appropriate 5 model output for the different biomes and is comparable to other transfer functions for the conversion of metadata from proxies into climatic data. These final sensitivities are now applied to the transient Holocene simulation to reconstruct the climate of selected time slices.

\section{Results}

\section{$10 \quad 3.1$ Time slice reconstructions}

Our results are presented for selected time slices of the Holocene: the late Holocene or present day (0 k: years 0-999 BP), the mid-Holocene (6 k: years 6000-6999 BP) and the early Holocene ( $9 \mathrm{k}$ : years 9000-9999 BP). These time slices are extracted from the transient Holocene simulation by taking the respective periods as references for

the reconstruction (Fig. 3). For the application of our method and Eq. (3), the temporal means over the whole time slices, i.e. $1000 \mathrm{yr}$, are used. $\Delta T$ is calculated as the difference between the mean over the time slice and the temporally corresponding mean of the proxy time series. Based on the seasonal sensitivities determined in Sect. 2.5 (Table 1), the $\Delta$ SST are deduced in a straightforward way. With these new sets of SST, the respective time slices are resimulated and compared to the corresponding time series of both the proxy and the PlaSim reference simulation. Consistent with Fig. 3, we first confine our comparison to the region, i.e. grid points of the Ammersee proxy. The outcome for the three time slices is shown in Fig. 6a-c. The time series of the proxy is always shown in dark gray (stairs), those of the transient reference simulation with prescribed SST in light gray and those with the reconstructed SST in black. The light (dark) gray bands are indicating the $1 \sigma$ and $2 \sigma$ ranges of the proxy. In $0 \mathrm{k}$

\section{ESDD}

3, 149-200, 2012

Reconstruction of

SST for terrestrial Holocene climate

K. Haberkorn et al.

Title Page

Abstract

Introduction

Conclusions

Tables

References

Figures

14

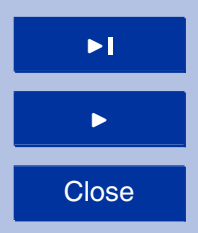

Back

Close

Printer-friendly Version

Interactive Discussion 
(Fig. 6a), PlaSim is warmer than the proxy in the reference experiment, despite some colder periods at the beginning of the time slice. Although the reconstruction leads to a decreasing mean temperature, PlaSim is still warmer over large parts of the $0 \mathrm{k}$ time slice. In $6 \mathrm{k}$ (Fig. 6b), the PlaSim reference simulation is colder than the Ammersee 5 proxy in the long-term mean despite some periods where PlaSim is warmer. After the reconstruction, the mean temperature is increasing, leading to a convergence of both time series. In the early Holocene (9 k, Fig. 6c), PlaSim is also colder in the longterm mean of the reference experiment, although longer periods exist, where PlaSim is warmer than the proxy. In the resimulation of the time slice with the reconstructed 10 SST, PlaSim becomes warmer in general, apart from only some years where PlaSim is colder. Apparent in all PlaSim time series is the much lower variability compared to the proxy, leading to a comparably smooth structure. An overview about the results of the reconstruction is presented in Table 2, where the time slice means of both the proxy and the PlaSim experiments including the $2 \sigma$-variability range as well as the anomalies 15 between the PlaSim simulations and the proxy are listed. In general terms, the means are converging in all time slices, leading to a strong improvement of the reconstruction over the reference experiment in $6 \mathrm{k}$ and especially in $9 \mathrm{k}$. However, regarding the statistical significance of the reconstructed time series (given by the shaded $\sigma$-ranges), the reconstruction of the mid-Holocene climate seems to show the best results, whereas it is only minor in the other two time slices, especially in $0 \mathrm{k}$. We interprete these results of limited statistical significance for the region of the Ammersee proxy with quantilequantile (qq) plots to provide a graphical comparison between reference and simulated data through relating the percentiles of the empirical cumulative distribution function of both data sets (Wilks, 2006). In case of a perfect match between both, all points will fall on the straight line, leading to the assumption of identically distributed data points. We compare the time series of the surface air temperature of the Ammersee proxy for the three time slices with the reference experiment (Fig. 7, left columns) as well as the reconstruction (right columns in Fig. 7). For the $0 \mathrm{k}$ time slice, the qq graph of the PlaSim data is above the proxy graph in the lower and higher range, whereas
ESDD

3, 149-200, 2012

\section{Reconstruction of SST for terrestrial Holocene climate}

K. Haberkorn et al.

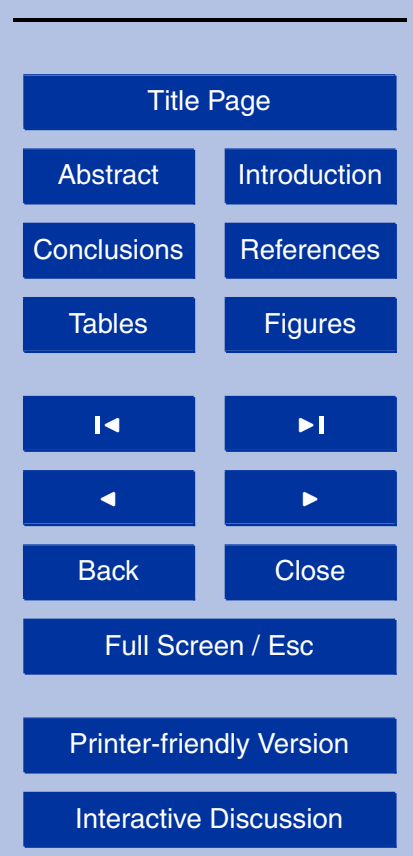


the central body fits well to the proxy distribution. The deviations in the lower (higher) range are indicative of a narrower (wider) distribution there. The overall differences between the reference and the reconstruction are only minor in $0 \mathrm{k}$, which is in line with the aforementioned results of only hardly converging time slice means. In the mid5 Holocene, the distribution of the PlaSim data is a bit wider in the lower range (indicated by the simulated data points below the proxy) which is even more pronounced in the reconstruction. Equally, the points are more similarly distributed in the mid range compared to the proxy, which is slightly improved in the reconstruction. The higher range is very similarly distributed in both PlaSim simulations. The results for the early Holocene 10 show the strongest deviations from the distribution of the proxy. In both the reference and the reconstructed time slice, the data points lie above the proxy in the lower range and below in the higher range, whereas the mid range is represented similarly. Consequently, the distribution of the PlaSim points is much narrower, i.e. the variability is lower and less extreme values occur. This is also clearly visible in Fig. 3 and in more detail in Fig. $6 \mathrm{c}$ and will be further discussed below. Although the reconstruction did not lead to a distinctive improvement of the distribution in $9 \mathrm{k}$, the convergence of the time means is strongest (Table 2), when compared to the other two time slices.

\subsection{Spatial pattern of European climate change}

The reconstruction of the land temperature for the region of the Ammersee proxy has 20 led to ambiguous results: converging time slice means, improving the representation of the mean proxy climate, are accompanied by statistically non-significant modifications after the SST-adjustment (except for $6 \mathrm{k}$ ). We will now test whether a statistical significant improvement is achieved when a wider region is considered, i.e. a higher number of grid points. In addition, as mentioned earlier in this study, we are not only in25 but rather in the climate changes for the whole region of Europe. The outcome of our reconstruction is now evaluated in terms of the spatial patterns of surface air temperature changes over Europe, presented as anomalies for all three time slices between

ESDD

3, 149-200, 2012

Reconstruction of SST for terrestrial Holocene climate

K. Haberkorn et al.

Title Page

Abstract Introduction

Conclusions

Tables References Figures

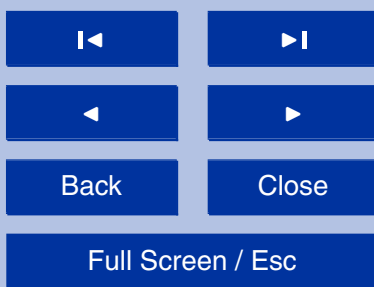

Printer-friendly Version

Interactive Discussion

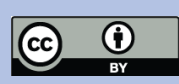


the reconstructed time slices and the corresponding ones of the reference simulation (Fig. 8a-c). Shown are only anomalies exceeding the $95 \%$-significance level of a two-tailed standard t-test. By doing so, the significant climate changes for Europe (non-significant areas are indicated in white), induced by the reconstructed SST, can 5 immediately be identified.

In accordance with the negative (positive) anomaly (Fig. 3 and Table 2) between the reference simulation and the proxy in $9 \mathrm{k}$ and $6 \mathrm{k}(0 \mathrm{k})$, the reconstruction leads to a warming (cooling) in the respective time slices, and exhibits antipodal patterns in all three time slices. The reconstruction of the SST leads to a spatially inconsistent pic10 ture, with the warming in $6 \mathrm{k}$ and $9 \mathrm{k}$ (Fig. $8 \mathrm{~b}$ and c) more pronounced in the western and eastern parts of Europe, i.e. the reference experiment is too cold there. Over central and northern Europe, the warming is less distinctive. It is strongest and more pronounced in both regions in $6 \mathrm{k}$. This may be indicative of a better representation of the mid-Holocene climatic optimum with the reconstructed SST based on the Am15 mersee proxy where the climate optimum is clearly visible (cf. Fig. 3). This hypothesis needs more investigation and can be verified in a future transient simulation with reconstructed SST. The cooling in $0 \mathrm{k}$ (Fig. 8a) is visible in the positive anomaly of the reference simulation and the proxy, and is also more pronounced in the western and eastern parts of Europe. These time slice means only show the changes over the whole period of $1000 \mathrm{yr}$ and suppress the submillennial - especially interannual - variability which may show a different picture for individual years. However, the statistical significance of our results is strongly increased when considering the European region and not only the grid points around the Ammersee proxy. Summing up, a very variable temperature distribution occurs over Europe during the Holocene. This can be clearly attributed to the incoming solar radiation as well as to the influence of the Laurentide ice shield, which persisted over North America during the early Holocene (Renssen et al., 2009). Both forcings affected the European climate differently: as Fig. 2 shows, the insolation signal was strongest in the early and mid-Holocene, inducing a warming mainly in the high northern latitudes. The impact of the Laurentide ice shield was
ESDD

3, 149-200, 2012

\section{Reconstruction of SST for terrestrial Holocene climate}

K. Haberkorn et al.

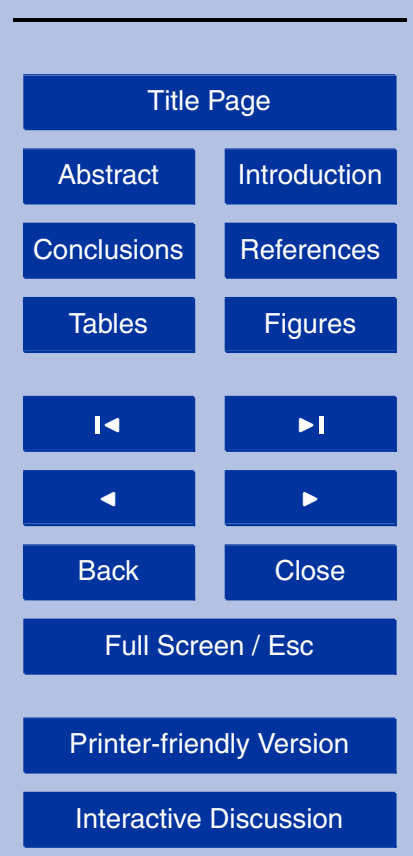


also most pronounced in the early time slices of the Holocene, however, it exerted a strong cooling in the high northern latitudes and thus counteracted the insolation induced warming. As Renssen et al. (2009) show, the ice shield determined to a large extent the timing and magnitude of the Holocene thermal maximum over the northern 5 high latitudes. We will further discuss the inherent difficulties of the ice sheet in the following section.

\subsection{Anomalies to preindustrial climate}

Anomalies to preindustrial climate are presented to enable a further concluding comparison to other climate reconstructions for Europe existing in the literature, and hence

10 a reflection of our results in a wider context. For preindustrial, a $200 \mathrm{yr}$ mean around the preindustrial year $1860(\triangleq 90 \mathrm{BP})$ is chosen, which is also taken from the PlaSim reference simulation.

The anomalies between the reference experiment time slices and preindustrial climate at a significance level of $95 \%$ are presented in Fig. 9. In 9 k (Fig. 9c), the climate 15 was colder than at preindustrial times, mainly in the northern and central parts of Europe where a cold anomaly can be observed. In the western and southern parts of Europe, a slight warming occurs. When we compare these findings to the anomaly between the reconstructed $9 \mathrm{k}$ time slice and the preindustrial (Fig. 10c), the pattern is more variable. In the northern high latitudes, a cooling can be still observed, but it is 20 weaker than before. Large parts of Europe, except central Europe, which also shows a cooling, are warmer than the preindustrial period. The reconstruction has even led to a warmer climate in regions which showed colder conditions in the reference simulation

For the time slice of the mid-Holocene $(6 \mathrm{k}$, Fig. 9b), the pattern is nearly identical compared to $9 \mathrm{k}$. A general cooling trend occurs in the anomaly of the reference simulation (Fig. 9b), which is a bit weaker in the northern high latitudes compared to $9 \mathrm{k}$, but stronger in the eastern parts of Europe. The warmer regions in the western and southern parts are less pronounced compared to $9 \mathrm{k}$. In the anomaly of the reconstructed $6 \mathrm{k}$ time slice (Fig. 10b), colder conditions only persist in central Europe and

\section{ESDD}

3, 149-200, 2012

\section{Reconstruction of SST for terrestrial Holocene climate}

K. Haberkorn et al.

Title Page

Abstract Introduction

Conclusions References

Tables Figures
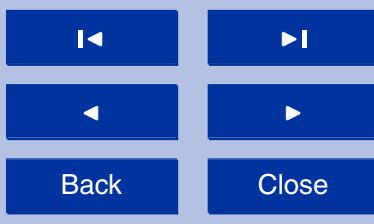

Full Screen / Esc

Printer-friendly Version

Interactive Discussion

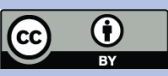


the high northern latitudes, but they are much weaker. On the contrary, the warming in the eastern and western parts of Europe is significantly more pronounced as in $9 \mathrm{k}$. In general it can be said, that nearly the whole region of Europe is characterized by warmer conditions compared to the preindustrial, which can be attributed by the 5 mid-Holocene climate optimum. Its representation in PlaSim is now much better than before.

For the $0 \mathrm{k}$ time slice (Fig. 9a), the trend is antipodal. The differences between the reference PlaSim simulation and preindustrial climate are very small with a slightly more pronounced cooling in the eastern parts of Europe. Due to the reconstruction 10 (Fig. 10a), the cooling intensifies, most strongly in the western and eastern parts of Europe, so the mean over the whole time slice is lower than the preindustrial mean.

\section{Discussion}

In the context of other reconstructions and Holocene simulations for the European region, our findings highlight potential benefits as well as deficiencies of the iterative 15 SST reconstruction method. Although our reconstruction is based only on the few grid points around the Lake Ammersee, Germany, the comparison of the extrapolated reconstructed climate to the whole region of Europe shows trends which are similar to those shown by other studies. Our results for the $6 \mathrm{k}$ time slice are consistent with Davis et al.'s (2003) temperature reconstruction. They found warmer conditions 20 over the northwestern, western and eastern central Europe during the mid-Holocene. Only the reconstruction, not the reference experiment agrees with this pollen-based reconstruction: clearly the reconstruction (Fig. 10b) performs better than the reference simulation (Fig. 9b) for this time slice. Further to the south, however, where our reconstruction indicates a warming, Davis et al. (2003) identified a cooling. This will be further discussed below.

The cold anomaly of the late Holocene $(0 \mathrm{k})$ as a result of the colder proxy climate can be expected from the slightly stronger $\mathrm{CO}_{2}$-forcing during the preindustrial period. The
ESDD

3, 149-200, 2012

Reconstruction of

SST for terrestrial Holocene climate

K. Haberkorn et al.

Title Page

Abstract

Introduction

Conclusions

References

Tables

Figures

14

D

4

Back

$\checkmark$

Close

Full Screen / Esc

Printer-friendly Version

Interactive Discussion

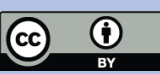


anomaly may still be underestimated, as can be seen from the lower time slice mean in the proxy compared to PlaSim. Nevertheless, a gap of several decades in the time series of the Ammersee proxy for $0 \mathrm{k}$ impedes a reliable temperature reconstruction. This may also be the reason for the remaining deviations in the distribution of the 5 PlaSim data (cf. Fig. 7a, right column). Besides this gap in the proxy time series, the results for this time slice show the feasibility of the method to not only adjust the model to a warmer but also to a colder climate (i.e. the symmetry of Eq. 2), as well as the inherent complexity of the adjustment being strongly dependent on the proxy data.

A closer look at the $9 \mathrm{k}$ time slice, of which the reconstruction shows weaker but 10 similar warming and cooling trends as the $6 \mathrm{k}$ time slice, shows less agreement with Davis et al. (2003). Although the results of the reconstruction for the Ammersee proxy showed the best approximation to the mean proxy climate for $9 \mathrm{k}$ (Table 2), the warming in most regions of Europe contrasts the cooling identified by Davis et al. (2003) - or others (Renssen et al., 2005, 2006).

15 As indicated before, comparing model results with proxy data always includes a range of obstacles which have to be considered. Proxies reflect climatic conditions on a very regional scale, which may indeed sometimes be representative for a larger region, as it is the case with the Ammersee proxy (cf. Sect. 2.2), and they are mainly influenced by local processes. These small scales cannot be resolved by the models as their resolution is mostly too coarse which precludes the incorporation of local processes potentially important for the proxies. Furthermore, these local influences may either be not fully understood or even completely unknown. Together with the coarse resolution, they contribute to the discrepancies in our results over southern Europe during $6 \mathrm{k}$ and also during $9 \mathrm{k}$, where comparably large spatial differences occur, whereas the model's time slice mean converges best to the proxy mean.

The study by Davis and Brewer (2009) sheds more light on this regional deviation, which was also identified in a recent study by Fischer and Jungclaus (2011) in their analysis of the mid-Holocene temperature cycle using a coupled atmosphere-ocean model. Comparing data from a new pollen-based reconstruction and output from the
ESDD

3, 149-200, 2012

\section{Reconstruction of SST for terrestrial Holocene climate}

K. Haberkorn et al.

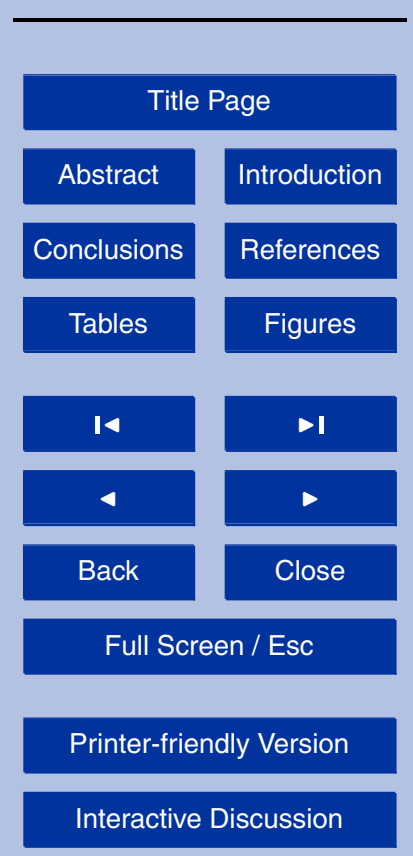


Paleoclimate Modelling Intercomparison Project (PMIP II, Braconnot et al., 2007a) with regard to an investigation of both the underlying mechanisms and responses of the orbital forcing (in terms of the latitudinal insolation gradient) on the climate system, Davis and Brewer (2009) found the same inconsistency in the southern European climate.

5 Without going too much into detail in this context, the authors argue that this can be largely attributed to how the models simulate the temperature response to a changing latitudinal insolation gradient between the mid and high northern latitudes (Raymo and Nisancioglu, 2003). Whereas the pollen data seem to be more sensitive to latitudinal insolation changes, models are more strongly influenced by the seasonal insolation. 10 This mismatch, together with the coarse model resolution, may thus contribute to this discrepancy.

Although both Davis and Brewer (2009) and Fischer and Jungclaus (2011) make assumptions about seasonal temperature changes, whereas we investigated annual changes, these findings can be seen in line with our results, as the seasonal insolation cycle is not only visible on seasonal time scales but also affects the annual mean climate response, thus the annual temperature changes are caused by seasonally different temperature changes (Braconnot et al., 2007b; Wanner et al., 2008; Fischer and Jungclaus, 2011). This again supports our approach of a seasonal adjustment of SST (cf. Sect. 2.5).

20 However, rather than to the reconstruction method, the deficiencies in the spatial reconstruction of the early Holocene time slice $(9 \mathrm{k})$ should also be attributed to northern high latitude climatic peculiarities of this time period, which is characterized by changing variability and the Laurentide ice sheet. Strong variability (cf. Fig. 7c) can be seen in the proxy time series at the early Holocene (Fig. 3). The anomalies between PlaSim 25 and the proxy alternate in sign on very short time scales. Whereas PlaSim is mostly warmer as the proxy in $10 \mathrm{kyr} \mathrm{BP}$, it is much more variable in $9 \mathrm{kyr} \mathrm{BP}$, which leads to the negative anomaly (Sect. 3.1). This complicates a reconstruction of this time slice, because the strong variability changes cannot be resimulated instantaneously. Secondly, and although the insolation was very strong, which would normally have induced a
ESDD

3, 149-200, 2012

\section{Reconstruction of SST for terrestrial Holocene climate}

K. Haberkorn et al.

Title Page

Abstract Introduction

Conclusions

Tables References Figures
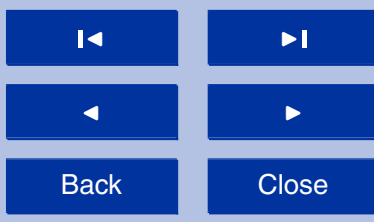

Back

Close

Printer-friendly Version

Interactive Discussion 
strong warming, the persisting Laurentide ice sheet strongly influenced the high northern latitudes and produced a no-analogue climate with both a weaker warming and a stronger cooling. This effect of the ice sheet on the climate of the northern regions has been investigated in many studies (e.g. Mitchell et al., 1988; Renssen et al., 2005). 5 The perturbing influence of the ice sheet further complicates the simulation of a realistic early Holocene climate. In contrast, the warmer mid-and late Holocene can be reconstructed by climate models more simply as a more or less direct response to the orbital forcing.

To account for the ice sheet-induced cooling, models either need to include a dy10 namic ice model or a reconstruction of the ice sheet (e.g. Peltier, 2004). The most frequent strategy was, however, to circumvent the ice sheet complication by leaving out early Holocene time slice simulations, and by choosing to simulate only transient time periods beginning after the retreat of the ice sheet (Lorenz et al., 2006; Renssen et al., 2009; Mann et al., 2009). By not considering the land ice despite palaeoclimatic 15 evidence, climate model simulations will always show a substantial bias. Our intention for setting up a Holocene experiment at the early Holocene without considering the land ice and therefore accepting this bias may be inconsistent but can be substantiated in several ways. Instead of analyzing the Holocene climate with PlaSim, our study intended mainly to introduce and to test this new method on the basis of the actual sheet reconstruction, affecting not only the mean climate state but also climate feedbacks. In addition, the general usefulness of this model-proxy-adjustment can also be argued for with regard to the problem of the missing land ice in climate models. By using this reconstruction method, one achieves the setup of realistic initial conditions for the beginning of the Holocene, where the climate model is tuned not only to colder temperatures but to existing palaeodata. Indeed, the missing land ice in the PlaSim simulation very likely contributes to the opposing warming trends in the model reconstruction versus the pollen reconstruction. Even when an ice sheet was considered, however, basing the reconstruction on only the $9 \mathrm{k}$ time slice would be inappropriate.
ESDD

3, 149-200, 2012

Reconstruction of SST for terrestrial Holocene climate

K. Haberkorn et al.

Title Page

Abstract Introduction

Conclusions

Tables References Figures

14

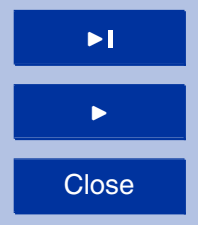

Back

Close

Printer-friendly Version

Interactive Discussion 
Instead, the full early Holocene climate should be considered, i.e. the $10 \mathrm{k}$ and $11 \mathrm{k}$ time slices in addition. Our future transient simulations will be initialized with the anomalies from the full early Holocene climate.

A problem which has become apparent due to the misleading results of the $9 \mathrm{k}$ time 5 slice points to a general limitation of our reconstruction method, because the adjustment can only take into account the prevailing conditions, i.e. the current climatic state (in terms of temperature) and not any variations on longer time scales. As the results of the $0 \mathrm{k}$ time slice reveal, the dependency of our reconstruction method on the proxy data can also be interpreted critically because it strongly relies on the quality of the 10 proxy data which therefore must be carefully chosen.

Whereas in this study, we focus on different time slices on the basis of currently one comparative proxy data, we intend on the one hand to carry out a full transient Holocene simulation with SST which are reconstructed on the basis of the proxy data, and on the other hand we will try to incorporate several proxies instead of only one. 15 The latter will then be consistent with other studies, relying on a wide range of different proxies (Renssen et al., 2009). Although the authors show similar trends as Davis et al. (2003) when comparing climate model output and proxy data from lake sediments, they also identify a comparably large discrepancy between models and proxy data in their intercomparison, which may be partly due to the fact that only one single proxy 20 is used as a reference (Renssen et al., 2009). Although in general, a certain bias must be accounted for when only considering one single proxy, the results by Renssen et al. (2009) are consistent and can thus be seen as an additional corroboration of our approach of relying the reconstruction on only one proxy before extending it to several proxies. For Europe, these multiple proxies can be expected to be in close vicinity 25 to each other. We assume a close proximity of these proxies to be of advantage for a successful reconstruction of the SST; Wirtz et al. (2010), for example, showed that on the spatial scale of few $1000 \mathrm{~km}$, the variability changes found in palaeoclimate time series are spatially coherent. For the aspired setup of a transient simulation, we expect improvements concerning the variability aspect and the overall outcome of this
ESDD

3, 149-200, 2012

\section{Reconstruction of SST for terrestrial Holocene climate}

K. Haberkorn et al.

Title Page

Abstract Introduction

Conclusions

Tables References Figures
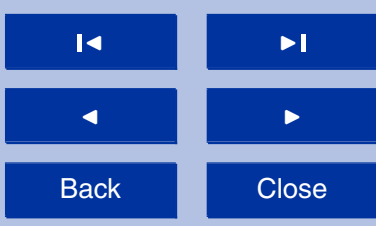

Back

Close

Printer-friendly Version

Interactive Discussion 
experiment. Application of these improvements leads to a modified version of Eq. (2), accounting for the transient mode in a first step:

$\frac{\partial S S T}{\partial \tau}=1 / \lambda \times\left[\bar{T}(\tau)-T_{\mathrm{P}}(\tau)\right]$

where $\bar{T}, T_{\mathrm{P}}$ and $1 / \lambda$ have the same meaning as before. $\tau$ is a slower time scale 5 ( $100 \mathrm{yr})$ and complies with the period of adjusting the SST. To incorporate several different proxies, we calculate

$\frac{\partial S S T}{\partial \tau}=1 / \lambda \sum_{n=1}^{N} \times\left[\bar{T}_{n}(\tau)-\bar{T}_{\mathrm{P}, n}(\tau)\right]$,

so Eq. (6) is simply adjusted to $n$ number of proxies used for the comparison, where $\bar{T}_{\mathrm{P}, n}$ is the mean over all the proxies which are taken into consideration. Some prob-

lems will come up with those modifications, especially concerning the inclusion of several proxies. When considering this, it must be kept in mind that proxies, even those which are located very close to each other, can show completely different (temperature) trends, caused by local phenomena affecting the proxies. For avoiding such an antipodal behavior, which may lead to an annihilation of the signal (positive versus negative

$15 \Delta T$ ), it should be considered of constraining on less proxies or only on those showing similar trends (Leduc et al., 2010).

\section{Conclusions}

We reconstructed regional SST patterns for the simulation of a Holocene climate which is constrained by terrestrial proxy data. Based on the sensitivity between the land cli20 mate and the SST, the latter can be reconstructed through a linear relationship. Our approach shows promising results with regard to a successful resimulation of the proxy climate: we seem to be able to adjust a GCM to a climate which is given by proxy data. Specifically, we obtain a better representation of the Holocene climate over Europe

\section{Reconstruction of SST for terrestrial Holocene climate}

K. Haberkorn et al.
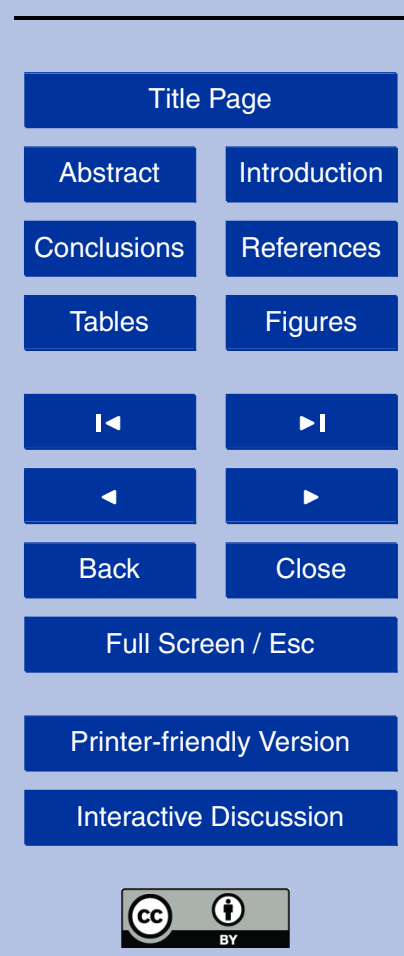
when compared to other proxy reconstructions - such as the mid-Holocene climate, which is considerably better illustrated in the reconstruction as in a reference Holocene experiment. In this context, this approach can be used to initialize a realistic simulation of the early Holocene, even in case of a missing dynamic ice sheet model and instead 5 of other land ice prescriptions. We envisage this land proxy-based reconstruction of sea surface temperature to become part of an ongoing process relating proxies and GCMs in an easy and straightforward way. As it is not based on statistical properties but on dynamical iterations, it may open new insights in this field. Our simple technique may seem too unsophisticated when thinking of the state-of-the-art coupled versions of existing GCMs - it is, however, very straightforward when keeping our actual intentions in mind of reconstructing a climate which shows the optimal fit to a specific proxy climate. We are interested mostly in the response of the atmosphere to the adjustment of the SST: thus, a disregard of oceanic feedbacks is permissible and in line with Widmann et al. (2010).

15 Acknowledgements. K. H. and C. L. are supported by the priority program INTERDYNAMIK of the German Research Foundation (DFG SPP 1266) and contribute to the project "Global Land Use and technological Evolution Simulations to Quantify Interactions between preindustrial Cultures and Climate". K. F. acknowledges financial support by a Max-Planck fellowship.

\section{References}

Ágústsdóttir, A. M.: Abrupt climate changes and the effects of North Atlantic deepwater formation: results from the GENESIS global climate model and comparison with data from the Younger Dryas event and the event at 8200 years BP and the present, Ph.D. thesis, The Pennsylvania State University, University Park, Pennsylvania, USA., 1998. 159

Alefs, J.: Feinstratigraphie und Diatomeensukzession in den Profundalsedimenten des Ammersees und Starnberger Sees (Oberbayern), Ph.D. thesis, Fak. f. Chem., Biol. und Geowiss. der Tech. Univ. München, Munich, Germany, 1997. 158

Alley, R. B. and Ágústsdóttir, A. M.: The 8k event: cause and consequences of a major Holocene abrupt climate change, Quaternary Sci. Rev., 24, 1123-1149, 2005. 158, 159

Alley, R. B., Mayewski, P. A., Sowers, T., Stuiver, M., Taylor, K. C., and Clark, P. U.: Holocene
ESDD

3, 149-200, 2012

\section{Reconstruction of \\ SST for terrestrial \\ Holocene climate}

K. Haberkorn et al.

\section{Title Page}

Abstract

Conclusions

References

Tables

Figures

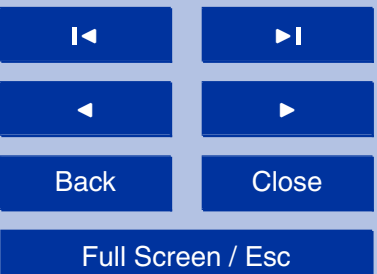

Printer-friendly Version

Interactive Discussion

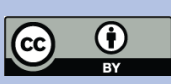


climatic instability: A prominent, widespread event 8200 yr ago, Geology, 25, 483-486, 1997. 158, 159

Bauer, E. and Ganopolski, A.: Simulation of the cold climate event 8200 years ago by meltwater outburst from Lake Agassiz, Paleoceanography, 19, PA3014, doi:10.1029/2004PA001030, $5 \quad$ 2004. 159

Berger, A.: Long-term variations of daily insolation and quarternary climatic change, J. Atmos. Sci., 35, 2362-2367, 1978b. 160

Berner, K. S., Koç, N., Divine, D., Godtliebsen, F., and Moros, M.: A decadal-scale Holocene sea surface temperature record from the subpolar North Atlantic constructed using diatoms and statistics and its relation to other climate parameters, Paleoceanography, 23, PA2210, doi:10.1029/2006PA001339, 2008. 153, 162

Blunier, T., Chappellaz, J., Schwander, J., Stauffer, B., and Raynaud, D.: Variations in atmospheric methane concentration during the Holocene epoch, Nature, 374, 46-49, 1995. 159

Boer, G. J. and Yu, B.: Climate sensitivity and response, Clim. Dynam., 20, 415-429, 2003. 15161,164

Bond, G., Showers, W., Cheseby, M., Lotti, R., Almasi, P., deMenocal, P., Priore, P., Cullen, H., Hajdas, I., and Bonani, G.: A pervasive millennial-scale cycle in North Atlantic Holocene and glacial climates, Science, 278, 2157-1266, 1997. 159

Bousquet, P., Ciais, P., Peylin, P., Ramonet, M., and Monfray, P.: Inverse modeling of annual atmospheric $\mathrm{CO}_{2}$ sources and sinks 1. Method and control inversion, J. Geophys. Res., 104, 26161-26178, 1999a. 153

Bousquet, P., Peylin, P., Ciais, P., Ramonet, M., and Monfray, P.: Inverse modeling of annual atmospheric $\mathrm{CO}_{2}$ sources and sinks 2 . Sensitivity study, J. Geophys. Res., 104, 2617926193, 1999b. 153

Braconnot, P., Otto-Bliesner, B., Harrison, S., Joussaume, S., Peterchmitt, J.-Y., Abe-Ouchi, A., Crucifix, M., Driesschaert, E., Fichefet, Th., Hewitt, C. D., Kageyama, M., Kitoh, A., Laîné, A., Loutre, M.-F., Marti, O., Merkel, U., Ramstein, G., Valdes, P., Weber, S. L., Yu, Y., and Zhao, Y.: Results of PMIP2 coupled simulations of the Mid-Holocene and Last Glacial Maximum Part 1: experiments and large-scale features, Clim. Past, 3, 261-277, doi:10.5194/cp-3-261$30 \quad 2007,2007$ a. 175

Braconnot, P., Otto-Bliesner, B., Harrison, S., Joussaume, S., Peterchmitt, J.-Y., Abe-Ouchi, A., Crucifix, M., Driesschaert, E., Fichefet, Th., Hewitt, C. D., Kageyama, M., Kitoh, A., Loutre, M.-F., Marti, O., Merkel, U., Ramstein, G., Valdes, P., Weber, L., Yu, Y., and Zhao, Y.:

\section{ESDD}

3, 149-200, 2012

\section{Reconstruction of \\ SST for terrestrial Holocene climate}

K. Haberkorn et al.

\section{Title Page}

Abstract

Introduction

Conclusions

References

Tables

Figures

14

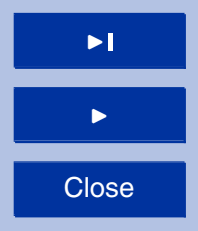

Back

Close

Full Screen / Esc

Printer-friendly Version

Interactive Discussion

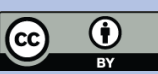


Results of PMIP2 coupled simulations of the Mid-Holocene and Last Glacial Maximum Part 2: feedbacks with emphasis on the location of the ITCZ and mid- and high latitudes heat budget, Clim. Past, 3, 279-296, doi:10.5194/cp-3-279-2007, 2007b. 175

Burke, A., Marchal, O., Bradtmiller, L. I., McManus, J. F., and François, R.: Application of an inverse method to interpret ${ }^{231} \mathrm{~Pa} /{ }^{230}$ Th observations from marine sediments, Paleoceanography, 26, PA1212, doi:10.1029/2010PA002022, 2011. 153

Claussen, M., Mysak, L. A., Weaver, A. J., Curcifix, M., Fichefet, T., Loutre, M.-F., Weber, S. L., Alcamo, J., Alexeev, V. A., Berger, A., Calov, R., Ganopolski, A., Goose, H., Lohmann, G., Lunkeit, F., Mokhov, I. I., Petoukhov, V., Stone, P., and Wang, Z.: Earth system models of intermediate complexity: closing the gap in the spectrum of climate system models, Clim. Dynam., 18, 579-586, 2002. 156

Czymzik, M., Dulski, P., Plessen, B., von Grafenstein, U., Naumann, R., and Brauer, A.: A 450 year record of spring-summer flood layers in annually laminated sediments from Lake Ammersee (southern Germany), Water Resour. Res., 46, W11528, doi:10.1029/2009WR008360, 2010. 158

Dansgaard, W.: Stable isotopes in precipitation, Tellus, 16, 436-468, 1964. 158

Davis, B. A. S. and Brewer, S.: Orbital forcing and role of the latitudinal insolation/temperature gradient, Clim. Dynam., 32, 143-165, 2009. 174, 175

Davis, B. A. S., Brewer, S., Stevenson, A., Guiot, J., and Contributors, D.: The temperature of 20 Europe during the Holocene reconstructed from pollen data, Quatern. Sci. Rev., 22, 17011716, 2003. 166, 173, 174, 177

Dekker, S. C., de Boer, H. J., Brovkin, V., Fraedrich, K., Wassen, M. J., and Rietkerk, M.: Biogeophysical feedbacks trigger shifts in the modelled vegetation-atmosphere system at multiple scales, Biogeosciences, 7, 1237-1245, doi:10.5194/bg-7-1237-2010, 2010. 155

Eliasen, E., Machenhauer, B., and Rasmussen, E.: On a numerical method for integration of the hydrodynamic equations with a spectral representation of the horizontal fields, report, Copenhagen, Denmark, 1970. 155

Fischer, N. and Jungclaus, J. H.: Effects of orbital forcing on atmosphere and ocean heat transports in Holocene and Eemian climate simulations with a comprehensive Earth system model, Clim. Past, 6, 155-168, doi:10.5194/cp-6-155-2010, 2010. 166

Fischer, N. and Jungclaus, J. H.: Evolution of the seasonal temperature cycle in a transient Holocene simulation: orbital forcing and sea-ice, Clim. Past, 7, 1139-1148, doi:10.5194/cp7-1139-2011, 2011. 174, 175

\section{ESDD}

3, 149-200, 2012

\section{Reconstruction of \\ SST for terrestrial Holocene climate}

K. Haberkorn et al.

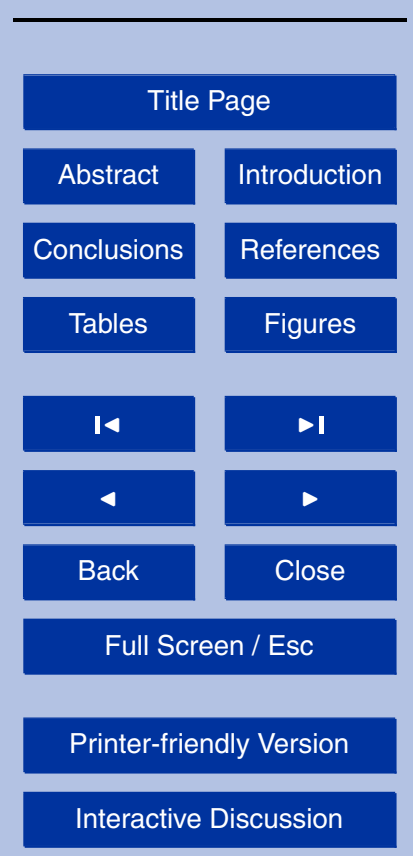


Fraedrich, K. and Lunkeit, F.: Diagnosing the entropy budget of a climate model, Tellus A, 60, 921-931, 2008. 155

Fraedrich, K., Kirk, E., Luksch, U., and Lunkeit, F.: The Portable University Model of the Atmosphere (PUMA): Strom track dynamics and low frequency variability, Meteorol. Z., 14, 735-745, 2005. 155

Gaillard, M.-J., Sugita, S., Mazier, F., Trondman, A.-K., Broström, A., Hickler, T., Kaplan, J. O., Kjellström, E., Kokfelt, U., Kuneš, P., Lemmen, C., Miller, P., Olofsson, J., Poska, A., Rundgren, M., Smith, B., Strandberg, G., Fyfe, R., Nielsen, A. B., Alenius, T., Balakauskas, L., Barnekow, L., Birks, H. J. B., Bjune, A., Björkman, L., Giesecke, T., Hjelle, K., Kalnina, L., Kangur, M., van der Knaap, W. O., Koff, T., Lagerås, P., Latałowa, M., Leydet, M., Lechterbeck, J., Lindbladh, M., Odgaard, B., Peglar, S., Segerström, U., von Stedingk, H., and Seppä, H.: Holocene land-cover reconstructions for studies on land cover-climate feedbacks, Clim. Past, 6, 483-499, doi:10.5194/cp-6-483-2010, 2010. 154

Garreta, V., Miller, P. A., Guiot, J., Hély, C., Brewer, S., Sykes, M. T., and Litt, T.: A method for climate and vegetation reconstruction through the inversion of a dynamic vegetation model, Clim. Dynam., 35, 371-389, 2010. 153

Gates, W. L.: AMIP: The Atmospheric Model Intercomparison Project, B. Am. Meteorol. Soc., 73, 1962-1970, 1992. 155

Göckede, M., Michalak, A. M., Vickers, D., Turner, D. P., and Law, B. E.: Atmospheric inverse modeling to constrain regional-scale $\mathrm{CO}_{2}$ budgets at high spatial and temporal resolution, J. Geophys. Res., 115, D15113, doi:10.1029/2009JD012257, 2010a. 153

Göckede, M., Turner, D. P., Michalak, A. M., Vickers, D., and Law, B. E.: Sensitivity of a subregional scale atmospheric inverse $\mathrm{CO}_{2}$ modeling framework to boundary conditions, J. Geophys. Res., 115, D24112, doi:10.1029/2010JD014443, 2010b. 153

Good, P., Gregory, J. M., and Lowe, J. A.: A step-response simple climate model to reconstruct and interpret AOGCM projections, Geophys. Res. Lett., 38, L01703, doi:10.1029/2010GL045208, 2011. 161

Goosse, H., Crespin, E., de Montety, A., Mann, M. E., Renssen, H., and Timmermann, A.: Reconstructing surface temperature changes over the past 600 years using climate model simulations with data assimilation, J. Geophys. Res., 115, D09108, doi:10.1029/2009JD012737, 2010. 151, 152

Gregory, J. M., Ingram, W. J., Palmer, M. A., Jones, G. S., Stott, P. A., Thorpe, R. B., Lowe, J. A., Johns, T. C., and Williams, K. D.: A new method for diagnosing radiative forcing and

ESDD

3, 149-200, 2012

\section{Reconstruction of \\ SST for terrestrial Holocene climate}

K. Haberkorn et al.
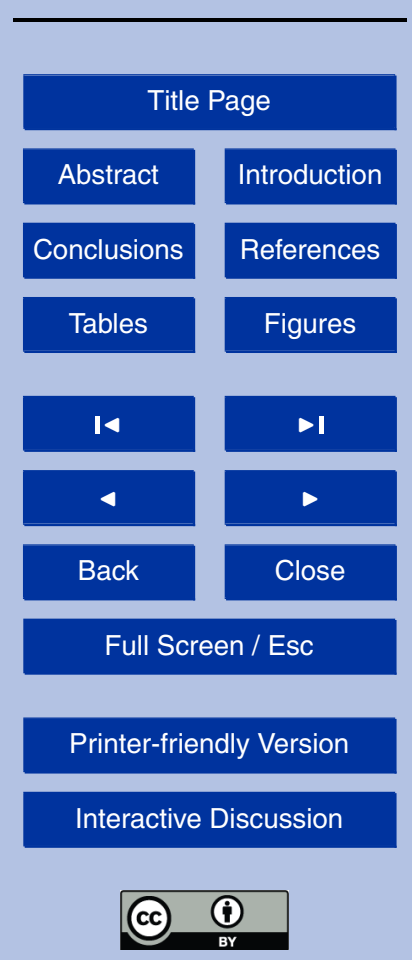
climate sensitivity, Geophys. Res. Lett., 31, L03205, doi:10.1029/2003GL018747, 2004. 161 Grosfeld, K., Lohmann, G., and Rimbu, N.: The impact of Atlantic and Pacific Ocean sea surface temperature anomalies on the North Atlantic multidecadal variability, Tellus, 60, 114, 2008. 153, 165

5 Guiot, J., Torre, F., Jolly, D., Peyron, O., Boreux, J. J., and Cheddadi, R.: Inverse vegetation modeling by Monte Carlo sampling to reconstruct paleoclimates under changed precipitation seasonality and $\mathrm{CO}_{2}$ conditions: application to glacial climate in Mediterranean region, Ecol. Model., 127, 119-140, 2000. 152, 163, 168

Guiot, J., Wu, H. B., Garreta, V., Hatté, C., and Magny, M.: A few prospective ideas on climate reconstruction: from a statistical single proxy approach towards a multi-proxy and dynamical approach, Clim. Past, 5, 571-583, doi:10.5194/cp-5-571-2009, 2009. 152, 163, 164

Haberkorn, K., Sielmann, F., Lunkeit, F., Kirk, E., Schneidereit, A., and Fraedrich, K.: Planet Simulator Climate, Scientific report, Hamburg, Germany, available at:http://www.mi. uni-hamburg.de/Downloads-un.245.0.html, last access: 5 September 2011, 2009. 155, 160

Indermühle, A., Stocker, T. F., Joos, F., Smith, H. J., Wahlen, M., Deck, B., Mastroianni, D., Tschumi, J., Blunier, T., Meyer, R., and Stauffer, B.: Holocene carbon-cycle dynamics based on $\mathrm{CO}_{2}$ trapped in ice at Taylor Dome, Antarctica, Nature, 398, 121-126, 1999. 160

Kållberg, P., Berrisford, P., Hoskins, B., Simmons, A., Uppala, S., Lamy-Thépaut, S., and Hine, R.: ERA-40 Project report series. 19. ERA-40 Atlas, ECMWF, workshop on Re-analysis,

20 Reading, United Kingdom, ECMWF, 2005. 151, 155

Kaplan, J. O., Krumhardt, K. M., Ellis, E. C., Ruddiman, W. F., Lemmen, C., and Klein Goldewijk, K.: Holocene carbon emissions as a result of anthropogenic land cover change, The Holocene, 21, 775-791, doi:10.1177/0959683610386983, 2011. 154

Kim, J.-H., Rimbu, N., Lorenz, S. J., Lohmann, G., Nam, S.-I., Schouten, S., Rühlemann, C., and Schneider, R. R.: North Pacific and North Atlantic sea-surface temperature variability during the Holocene, Quarternary Sci. Rev., 23, 2141-2154, 2004. 153, 163

Klitgaard-Kristensen, D., Sejrup, H. P., Haflidason, H., Johnsen, S., and Spurk, M.: A regional 8200 cal. yr BP cooling event in northwest Europe, induced by final stages of the Laurentide ice-sheet deglaciation?, J. Quaternary Sci., 13, 165-169, 1998. 159

30 Kuo, $\mathrm{H}$.: On formation and intensification of tropical cyclones through latent heat release by cumulus convection, J. Atmos. Sci., 22, 40-63, 1965. 155

Kuo, $\mathrm{H}$.: Further studies of the parameterization of the influence of cumulus convection on large-scale flow, J. Atmos. Sci., 31, 1232-1240, 1974. 155
ESDD

3, 149-200, 2012

\section{Reconstruction of \\ SST for terrestrial \\ Holocene climate}

K. Haberkorn et al.

\section{Title Page}

Abstract

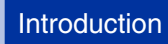

Conclusions

References

Tables

Figures

14

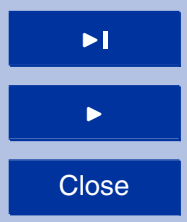

Back

Close

\section{Full Screen / Esc}

Printer-friendly Version

Interactive Discussion

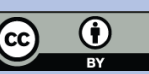


Lacis, A. A. and Hansen, J. E.: A parameterization for the absorption of solar radiation in the Earth's atmosphere, J. Atmos. Sci., 31, 118-133, 1974. 155

Laepple, T. and Lohmann, G.: Seasonal cycle as template for climate variability on astronomical timescales, Paleoceanography, 24, PA4201, doi:10.1029/2008PA001674, 2009. 164, 165

5 Laursen, L. and Eliasen, E.: On the effect of the damping mechanisms in an atmospheric general circulation model, Tellus, 41, 385-400, 1989. 155

Leduc, G., Schneider, R., Kim, J.-H., and Lohmann, G.: Holocene and Eemian sea surface temperature trends as revealed by alkenone and $\mathrm{Mg} / \mathrm{Ca}$ paleothermometry, Quaternary Sci. Rev., 29, 989-1004, 2010. 162, 166, 178

Lemmen, C.: World distribution of land cover changes during Pre- and Protohistoric Times and estimation of induced carbon releases, in: Geoarchaeology: human-environment connectivity, edited by: Ghilardi, M., Fouache, E., and Chiverrell, R., Géomorphologie: relief, processus, environnement, 4, 303-312, 2009. 154

Lemmen, C., Gronenborn, D., and Wirtz, K. W.: A simulation of the Neolithic transition in 15 Western Eurasia, J. Archaol. Science, 38, 3459-3470, doi:10.1016/j.jas.2011.08.008, 2011. 154

Ljungqvist, F. C., Krusic, P. J., Brattström, G., and Sundqvist, H. S.: Northern Hemisphere temperature patterns in the last 12 centuries, Clim. Past, 8, 227-249, doi:10.5194/cp-8-2272012, 2012. 162, 164

20 Löptien, U. and Ruprecht, E.: Effect of synoptic systems on the variability of the North Atlantic Oscillation, Mon. Weather Rev., 133, 2894-2904, 2005. 165

Lorenz, S. J., Kim, J.-H., Rimbu, N., Schneider, R. R., and Lohmann, G.: Orbitally driven insolation forcing on Holocene climate trends: Evidence from alkenone data and climate modeling, Paleoceanography, 21, PA1002, doi:10.1029/2005PA001152, 2006. 163, 176

Louis, J.-F.: A parametric model of vertical eddy fluxes in the atmosphere, Bound.-Lay. Meteorol., 17, 187-202, 1979. 155

Louis, J.-F., Tiedke, M., and Geleyn, J.-F.: A short history of the PBL parameterisation at ECMWF, in: Proceedings of the ECMWF Workshop on Planetary Boundary Layer Parameterization, Reading, 25-27 November 1981, 59-80, 1982. 155

30 Lucarini, V., Fraedrich, K., and Lunkeit, F.: Thermodynamic analysis of snowball earth hysteresis experiment: efficiency, entropy production, and irreversibility, Q. J. Roy. Meterol. Soc., 136, 2-11, 2010. 155

Lunkeit, F., Böttinger, M., Fraedrich, K., Jansen, H., Kirk, E., Kleidon, A., and Luksch, U.:
ESDD

3, 149-200, 2012

\section{Reconstruction of \\ SST for terrestrial \\ Holocene climate}

K. Haberkorn et al.

\section{Title Page}

Abstract

Introduction

Conclusions

References

Tables

Figures

14

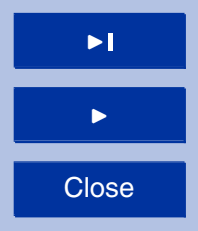

Back

Close

Printer-friendly Version

Interactive Discussion 
Planet Simulator, Reference Manual, Version 16.0, available at: http://www.mi.uni-hamburg. de/Downloads-un.245.0.html, last access: 5 September 2011, 2010. 155

Maier-Reimer, E., Mikolajewicz, U., and Hasselmann, K.: Mean circulation of the Hamburg LSG OGCM and its sensitivity to the thermohaline surface forcing, J. Phys. Oceanogr., 23, $5 \quad$ 731-757, 1993. 156

Mann, M. E., Schmidt, G. A., Miller, S. K., and LeGrande, A. N.: Potential biases in inferring Holocene temperature trends from long-term borehole information, Geophys. Res. Lett., 36, L05708, doi:10.1029/2005PA001152, 2009. 176

Mayewski, P. A., Rohling, E. E., Sager, J. C., Karlén, W., Maasch, K. A., Meeker, L., Meyerson, E. A., Gasse, F., van Kreveld, S., Holmgren, K., Lee-Thorp, J., Rosqvist, G., Rack, F., Staubwasser, M., Schneider, R. R., and Steig, E. J.: Holocene climate variability, Quaternary Res., 62, 243-255, 2004. 153

Mitchell, J. F. B., Grahame, N. S., and Needham, K. J.: Climate simulations for 9000 years before present - Seasonal Variations and effect of the Laurentide Ice-Sheet, J. Geophys. Res., 93, 8283-8303, 1988. 176

Olofsson, J. and Hickler, T.: Effects of human land-use on the global carbon cycle during the last 6,000 years, Veg. His. Archaeobot., 17, 605-615, 2008. 154

Orszag, S. A.: Transform Method for calculation of vector coupled sums, J. Atmos. Sci., 27, 890-895, 1970. 155

20 Pachauri, R. K. and Reisinger, A. (Eds.): IPCC, 2007: Climate Change 2007: Synthesis Report. Contribution of Working Groups I, II and III to the Fourth Assessment Report of the Intergovernmental Panel on Climate Change, p. 104, IPCC, Geneva, Switzerland, 2007. 161

Peltier, W.: Global Glacial Isostasy and the Surface of the Ice-Age Earth: The ICE-5G (VM2) Model and GRACE, Ann. Rev. Earth Planet. Sci., 32, 111-149, 2004. 176

Raymo, M. E. and Nisancioglu, K.: The 41 kyr world: Milankovitch's other unsolved mystery, Paleoceanography, 18, 1011, doi:10.1029/2002PA000791, 2003. 175

Renssen, H., Goosse, H., Fichefet, T., and Campin, J.-M.: The 8.2 kyr BP event simulated by a global atmosphere-sea-ice-ocean model, Geophys. Res. Lett., 28, 1567-1570, 2001. 159

Renssen, H., Goosse, H., and Fichefet, T.: Modeling the effect of freshwater pulses on the early Holocene climate: The influence of high-frequency climate variability, Paleoceanography, 17, 1020, doi:10.1029/2001PA000649, 2002. 159

Renssen, H., Goosse, H., Fichefet, T., Brovkin, V., Driesschaert, E., and Wolk, F.: Simulating the Holocene climate evolution at northern high latitudes using a coupled atmosphere-sea

\section{ESDD}

3, 149-200, 2012

\section{Reconstruction of \\ SST for terrestrial \\ Holocene climate}

K. Haberkorn et al.

\section{Title Page}

Abstract

Introduction

Conclusions

References

Tables

Figures

14

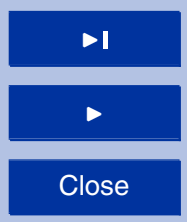

Back

Close

\section{Full Screen / Esc}

Printer-friendly Version

Interactive Discussion

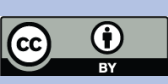


ice-ocean-vegetation model, Clim. Dynam., 24, 23-43, 2005. 174, 176

Renssen, H., Goosse, H., and Muscheler, R.: Coupled climate model simulation of Holocene cooling events: oceanic feedback amplifies solar forcing, Clim. Past, 2, 79-90, doi:10.5194/cp-2-79-2006, 2006. 174

5 Renssen, H., Seppä, H., Heiri, O., Roche, D. M., Goosse, H., and Fichefet, T.: The spatial and temporal complexity of the Holocene thermal maximum, Nat. Geosci., 513, 1-4, 2009. 171, $172,176,177$

Rimbu, N., Lohmann, G., Kim, J.-H., Arz, H. W., and Schneider, R.: Arctic/North Atlantic Oscillation signature in Holocene sea surface temperature trends as obtained from alkenone data, Geophys. Res. Lett., 30, 1280, doi:10.1029/2002GL016570, 2003. 153

Rimbu, N., Lohmann, G., Lorenz, S. J., and Kim, J. H.: Holocene climate variability as derived from alkenone sea surface temperature and coupled ocean-atmosphere model experiments, Clim. Dynam., 23, 215-227, 2004. 153, 163

Rodwell, M. J., Rowell, D. P., and Folland, C. K.: Oceanic forcing of the wintertime North Atlantic 15 Oscillation and European climate, Nature, 398, 320-323, 1999. 164

Roeckner, E., Arpe, K., and Bengtsson, L.: Simulation of present-day climate with the ECHAM model: Impact of model physics and resolution, Tech. Rep., 93, Max -Planck-Institut, Hamburg, Germany, 1992. 155

Rohling, E. J., Mayewski, P. A., Abu-Zied, R. H., Casford, J. S. L., and Hayes, A.: Holocene atmosphere-ocean interactions: records from Greenland and the Aegean Sea, Clim. Dynam., 18, 587-593, 2002. 158

Rozanski, K., Araguás-Araguás, L., and Gonfiantini, R.: Relation between long-term trends of oxygen-18 isotope composition of precipitation and climate, Science, 258, 981-985, 1992. 158

Sasamori, T.: The radiative cooling calculation for application to general circulation experiments, J. Appl. Meteorol., 7, 721-729, 1968. 155

Schmittner, A., Silva, T. A. M., Fraedrich, K., Kirk, E., and Lunkeit, F.: Effects of mountains and ice sheets on global ocean circulation, J. Climate, 24, 2814-2829, 2011. 156

Schneider, B., Leduc, G., and Park, W.: Disentangling seasonal signals in Holocene 30 climate trends by satellite-model-proxy integration, Paleoceanography, 25, PA4217, doi:10.1029/2009PA001893, 2010. 166

Slingo, A. and Slingo, J. M.: Response of the National Center for Atmospheric Research community climate model to improvements in the representation of clouds, J. Geophys. Res., 96,
ESDD

3, 149-200, 2012

\section{Reconstruction of \\ SST for terrestrial \\ Holocene climate}

K. Haberkorn et al.

Title Page

Abstract

Introduction

Conclusions

References

Tables

Figures

14

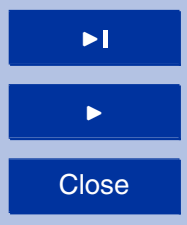

Back

Close

Full Screen / Esc

Printer-friendly Version

Interactive Discussion

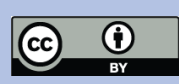


341-357, 1991. 155

Stephens, G. L.: Radiation profiles in extended water clouds. II: Parameterization schemes, J. Atmos. Sci., 35, 2123-2132, 1978. 155

Stephens, G. L., Ackermann, S., and Smith, E. A.: A shortwave parameterization revised to improve cloud absorption, J. Atmos. Sci., 41, 687-690, 1984. 155

Sundqvist, H. S., Zhang, Q., Moberg, A., Holmgren, K., Körnich, H., Nilsson, J., and Brattström, G.: Climate change between the mid and late Holocene in northern high latitudes - Part 1: Survey of temperature and precipitation proxy data, Clim. Past, 6, 591-608, doi:10.5194/cp6-591-2010, 2010. 164

10 Sutton, R. T. and Hodson, D. L. R.: Influence of the Ocean on North Atlantic climate variability 1871-1999, J. Climate, 16, 3296-3313, 2003. 165

Sutton, R. T. and Hodson, D. L. R.: Atlantic ocean forcing of North American and European summer climate, Science, 309, 115-118, 2005. 165

Taylor, K. E., Williamson, D., and Zwiers, F.: The sea surface temperature and sea-ice concentration boundary condition for AMIP II simulations, in: PCMDI Report Series, 60, Program for Climate Model Diagnosis and Intercomparison, University of California, Lawrence Livermore National Laboratory, Livermore, CA, USA, 2000. 155

Uppala, S., Kallberg, P., Simmons, A., Andrae, U., da Costa Bechtold, V., Fiorino, M., Gibson, J., Haseler, J., Hernandez, A., Kelly, G. ., Li, X., Onogi, K., Saarinen, S., Sokka, N., an d E. Andersson, R. A., Arpe, K., Imaseda, M. B., Beljaars, A., van d e Berg, L., Bidlot, J., Bormann, N., Caires, S., Chevallier, F., Dethof, A., Dragosavac, M., Fisher, M., Fuentes, M., Hagemann, S., Holm, E., Hoskins, B., Isaksen, L., Janssen, P., Jenne, R., McNally, A., Mahfouf, J.-F., Morcrette, J.-J., Rayner, N., Saunders, R., Simon, P., Sterl, A., Trenberth, K., Untch, A., Vasiljevic, D., Viterbo, P., and Woollen, J.: The ERA-40 re-analysis, Q. J. Roy. Meteorol. Soc., 131, 2961-3012, 2005. 155

von Grafenstein, U., Erlenkeuser, H., Müller, J., Jouzel, J., and Johnsen, S.: The cold event 8200 years ago documented in oxygen isotope records of precipitation in Europe and Greenland, Clim. Dynam., 14, 73-81, 1998. 157, 158, 159, 191

von Grafenstein, U., Erlenkeuser, H., Brauer, A., Jouzel, J., and Johnsen, S. J.: A Mid-European 30 decadal isotope-climate record from 15,500 to 5000 years B.P., Science, 4, 1654-1657, 1999. 158

von Grafenstein, U.: Ammersee Ostracod Oxygen Isotope Data, IGBP PAGES/World Data Center for Paleoclimatology Data Contribution Series \# 2003-068, NOAA/NGDC Paleocli-
ESDD

3, 149-200, 2012

\section{Reconstruction of \\ SST for terrestrial \\ Holocene climate}

K. Haberkorn et al.

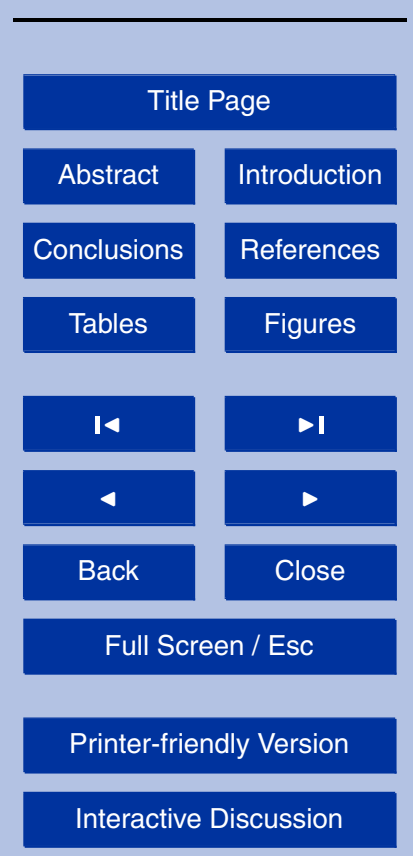


matology Program, Boulder CO, USA, 2003. 157

Wanner, H., Beer, J., Bütikofer, J., Crowley, T. J., Cubasch, U., Flückiger, J., Goosse, H., Grosjean, M., Joos, F., Kaplan, J. O., Küttel, M., Müller, S. A., Prentice, I. C., Solomina, O., Stocker, T. F., Tarasov, P., Wagner, M., and Widmann, M.: Mid- to Late Holocene climate change: an overview, Quaternary Sci. Rev., 27, 1791-1828, 2008. 153, 160, 175

Weldeab, S., Schneider, R. R., and Müller, P.: Comparison of Mg/Ca-and alkenone-based sea surface temperature estimates in the fresh water-influenced Gulf of Guinea, eastern equatorial Atlantic, S. Weldeab, 8, Q05P22, doi:10.1029/2006GC001360, 2007. 163

Widmann, M., Goosse, H., van der Schrier, G., Schnur, R., and Barkmeijer, J.: Using data assimilation to study extratropical Northern Hemisphere climate over the last millennium, Clim. Past, 6, 627-644, doi:10.5194/cp-6-627-2010, 2010. 151, 152, 163, 179

Wiersma, A. W. and Renssen, H.: Model-data comparison for the 8.2 ka BP event: confirmation of a forcing mechanism by catastrophic drainage of Laurentide Lakes, Quaternary Sci. Rev., 25, 63-88, 2006. 158, 159

Wilks, D. S.: Statistical methods in the atmospheric sciences, 2nd edition, Academic Press, San Diego, 2006. 169

Wilson, R., Cook, E., D’Arrigo, R., Riedwyl, N., Evans, M., Tudhope, A., and Allan, R.: Reconstructing ENSO: the influence of method, proxy data, climate forcing and teleconnections, J. Quaternary Sci., 25, 62-78, doi:10.1002/jqs.1297, 2010. 161, 164

20

Wirtz, K. W., Lohmann, G., Bernhardt, K., and Lemmen, C.: Mid-Holocene regional reorganization of climate variability: Analyses of proxy data in the frequency domain, Palaeogeogr. Palaeocl., 298, 189-200, doi:10.1016/j.palaeo.2010.09.019, 2010. 153, 156, 157, 161, 163, 177

Wu, H., Guiot, J., Brewer, S., and Guo, Z.: Climatic changes in Eurasia and Africa at the last glacial maximum and mid-Holocene: reconstruction from pollen data using inverse vegetation modelling, Clim. Dynam., 29, 211-229, 2007. 152, 153, 163, 164, 168
ESDD

3, 149-200, 2012

\section{Reconstruction of \\ SST for terrestrial \\ Holocene climate}

K. Haberkorn et al.

\section{Title Page}

Abstract

Introduction

Conclusions

References

Tables

Figures

14

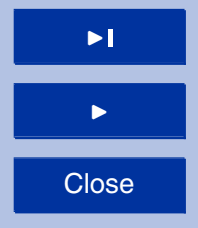

Back

Close

Full Screen / Esc

Printer-friendly Version

Interactive Discussion

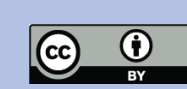




\section{ESDD}

3, 149-200, 2012

\section{Reconstruction of SST for terrestrial Holocene climate}

Table 1. Overview of results of experiments using annual and seasonal sensitivities.

\begin{tabular}{|c|c|c|c|}
\hline Sensitivity & $\Delta T_{\text {ann }}$ & $\Delta S S T$ & $\Delta T_{\text {sim, ann }}$ \\
\hline $\begin{array}{l}\text { constant, } \\
\text { annual }\end{array}$ & $+1.5^{\circ} \mathrm{C}$ & $+2.71^{\circ} \mathrm{C}$ & $+1.62^{\circ} \mathrm{C}$ \\
\hline $\begin{array}{l}\text { seasonally } \\
\text { dependent }\end{array}$ & $+1.5^{\circ} \mathrm{C}$ & $\begin{array}{r}\text { MAM: }+2.71^{\circ} \mathrm{C} \\
\text { SON: }+2.71^{\circ} \mathrm{C} \\
\text { DJF: }+2.0^{\circ} \mathrm{C} \\
\text { JJA: }+3.4^{\circ} \mathrm{C}\end{array}$ & $+1.51^{\circ} \mathrm{C}$ \\
\hline $\begin{array}{l}\text { Final } \\
\text { seasonal } \\
\text { sensitivities }\end{array}$ & $\begin{array}{r}\lambda_{\text {DJF }} \\
\lambda_{\text {MAM }} \\
\lambda_{\text {SON }} \\
\lambda_{\text {JJA }}\end{array}$ & $\begin{aligned} & =0.75 \\
= & 0.5532 \\
= & 0.5532 \\
= & 0.4411\end{aligned}$ & \\
\hline
\end{tabular}

Title Page

Abstract

Introduction

Conclusions

References

Tables

Figures

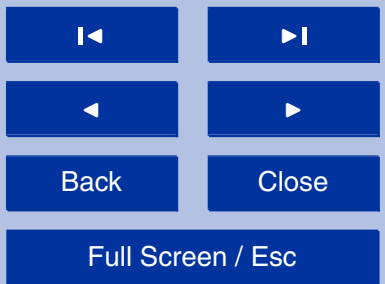

Printer-friendly Version

Interactive Discussion 


\section{ESDD}

3, 149-200, 2012

\section{Reconstruction of SST for terrestrial Holocene climate}

K. Haberkorn et al.

Table 2. Time slice means and $2 \sigma$-significance for the Ammersee proxy (left column), PlaSim reference (second left column), PlaSim reconstructed (middle column) and anomalies between PlaSim reference and the proxy $\Delta T_{1}$ (second right column) and between PlaSim reconstructed and the proxy $\Delta T_{2}$ (right column).

\begin{tabular}{rrrrrr}
\hline & & PlaSim & PlaSim & & \\
& Proxy $\pm 2 \sigma$ & reference $\pm 2 \sigma$ & reconstructed $\pm 2 \sigma$ & $\Delta T_{1} \pm 2 \sigma$ & $\Delta T_{2} \pm 2 \sigma$ \\
\hline $0 \mathrm{k}$ & $8.26 \pm 1.34^{\circ} \mathrm{C}$ & $8.95 \pm 1.44^{\circ} \mathrm{C}$ & $8.74 \pm 1.44^{\circ} \mathrm{C}$ & $0.69 \pm 1.94^{\circ} \mathrm{C}$ & $0.48 \pm 2.04^{\circ} \mathrm{C}$ \\
$6 \mathrm{k}$ & $9.09 \pm 1.0^{\circ} \mathrm{C}$ & $8.36 \pm 1.27^{\circ} \mathrm{C}$ & $8.90 \pm 1.04^{\circ} \mathrm{C}$ & $-0.73 \pm 1.48^{\circ} \mathrm{C}$ & $-0.18 \pm 1.41^{\circ} \mathrm{C}$ \\
$9 \mathrm{k}$ & $8.66 \pm 1.95^{\circ} \mathrm{C}$ & $8.32 \pm 1.20^{\circ} \mathrm{C}$ & $8.69 \pm 1.04^{\circ} \mathrm{C}$ & $-0.34 \pm 2.35^{\circ} \mathrm{C}$ & $0.03 \pm 2.21^{\circ} \mathrm{C}$ \\
\hline
\end{tabular}

Title Page

Abstract

Introduction

Conclusions

References

Tables

Figures

14

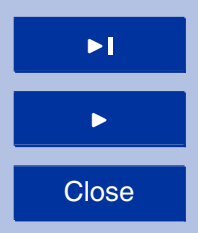

Back

Close

Full Screen / Esc

Printer-friendly Version

Interactive Discussion

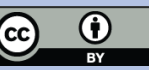




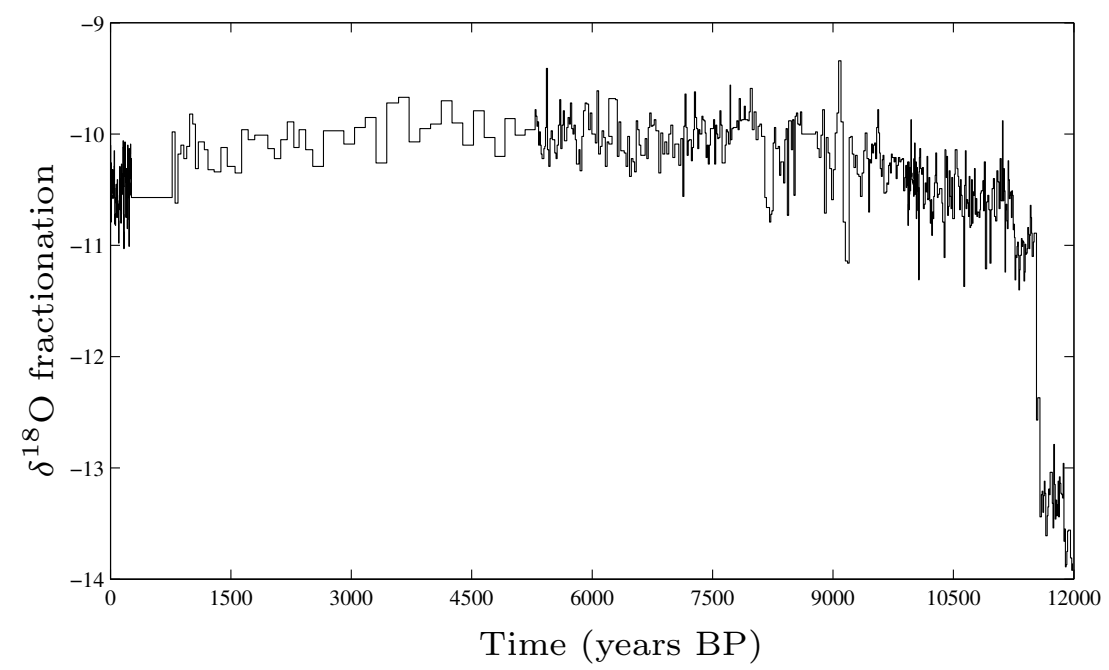

ESDD

3, 149-200, 2012

Reconstruction of SST for terrestrial Holocene climate

K. Haberkorn et al.

Title Page

\section{Abstract}

Introduction

Conclusions

References

Tables

Figures
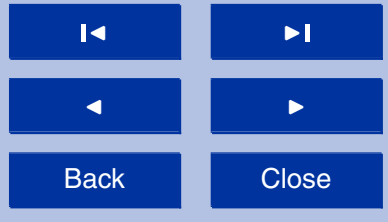
et al., 1998) from 0 to $12 \mathrm{kyr} \mathrm{BP}$.

Full Screen / Esc

Printer-friendly Version

Interactive Discussion 


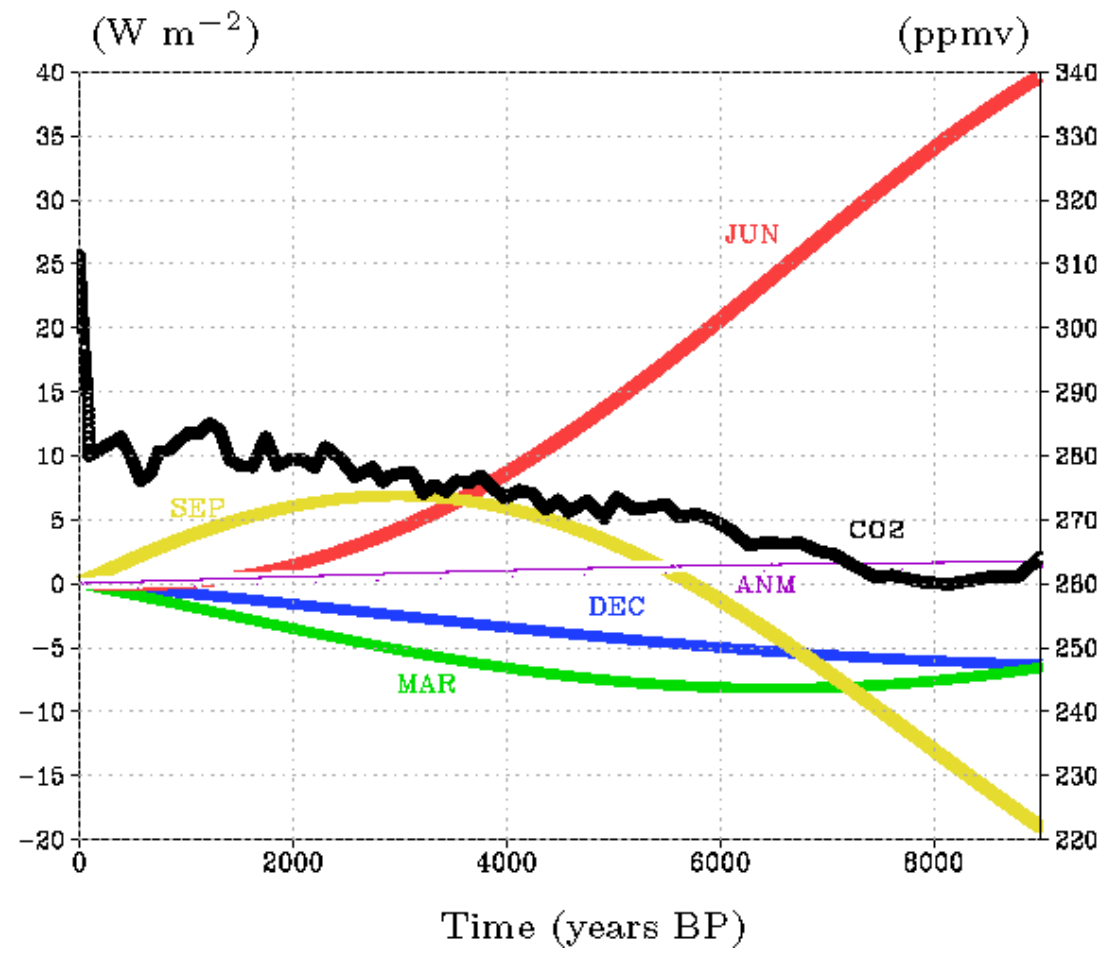

Fig. 2. Applied orbital forcing (given by the seasonal insolation at $60^{\circ} \mathrm{N}$, shown as the anomaly relative to $0 \mathrm{kyr} B P$ ) and greenhouse gas forcing (given by the atmospheric concentration of $\mathrm{CO}_{2}$ ).

\section{ESDD}

3, 149-200, 2012

\section{Reconstruction of SST for terrestrial Holocene climate \\ K. Haberkorn et al.}

\section{Title Page}

\begin{tabular}{c|c|}
\hline Abstract & Introduction \\
\hline Conclusions & References \\
\hline Tables & Figures \\
\hline I4 & - I \\
\hline 4 & - \\
\hline Back & Close \\
\hline Full Screen / Esc \\
\hline
\end{tabular}

Printer-friendly Version

Interactive Discussion

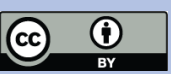




\section{ESDD}

3, 149-200, 2012

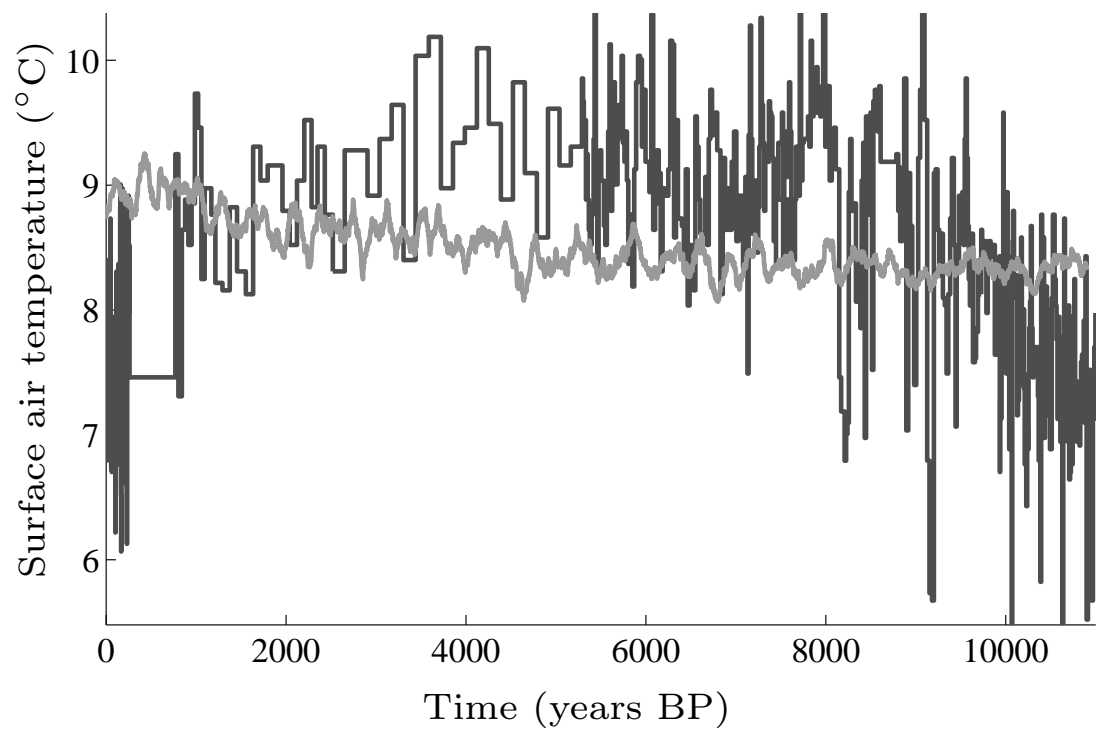

Fig. 3. Reconstructed annual mean surface air temperature $\left({ }^{\circ} \mathrm{C}\right)$ for the Ammersee proxy (dark gray) and the respective time series (100 year running mean) simulated by PlaSim (light gray) from 0 to $11 \mathrm{kyrBP}$.

\section{Reconstruction of SST for terrestrial Holocene climate}

K. Haberkorn et al.

\section{Title Page}

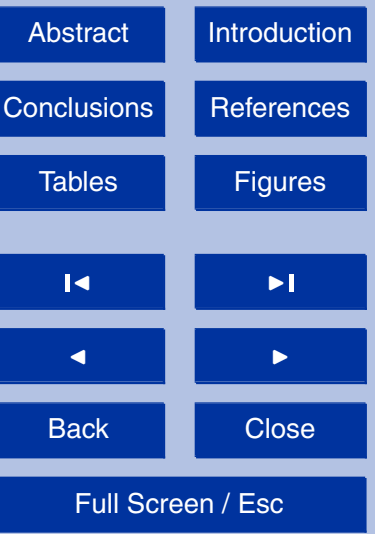

Printer-friendly Version

Interactive Discussion 


\section{ESDD}

3, 149-200, 2012

$\Delta S S T \stackrel{\lambda}{\longrightarrow} \Delta \bar{T}$

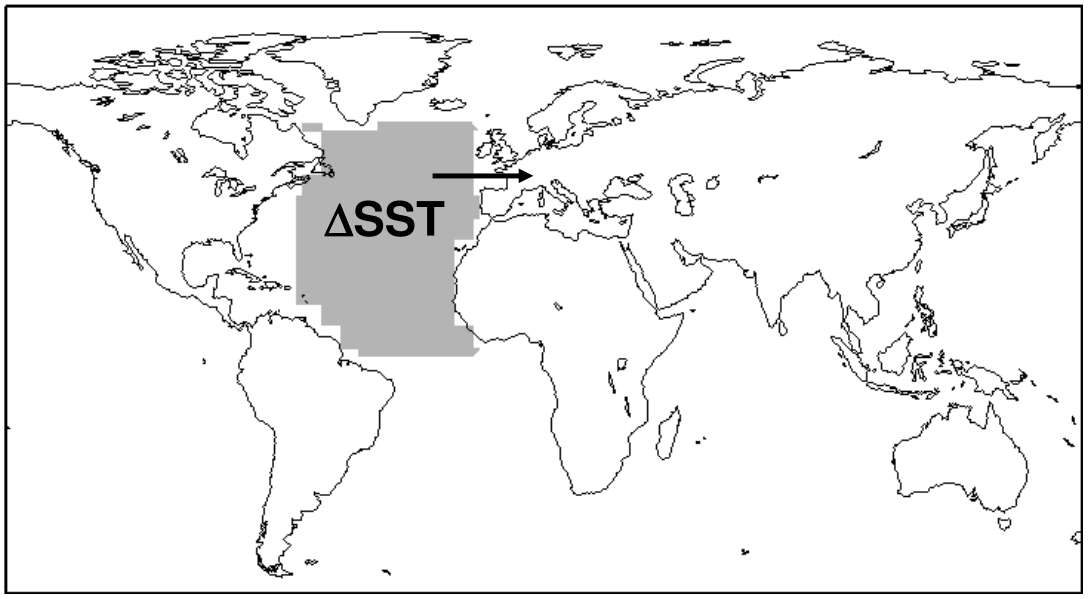

Fig. 4. Relationship as determined in Eq. (1) between SST anomalies and land climate, corrected by the sensitivity $\lambda$. The forcing (source) region is the North Atlantic $\left(0^{\circ}\right.$ and $\left.60^{\circ} \mathrm{N}\right)$, which has the strongest influence on the European land (target) climate as indicated by terrestrial proxy data.

\section{Reconstruction of SST for terrestrial Holocene climate \\ K. Haberkorn et al. \\ Title Page \\ Abstract \\ Introduction \\ Conclusions \\ References \\ Tables \\ Figures

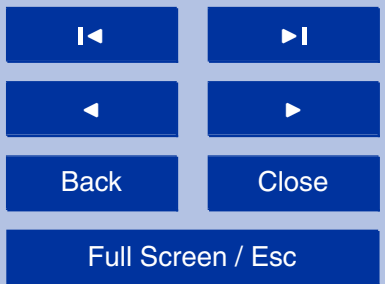

Printer-friendly Version

Interactive Discussion 


\section{ESDD}

3, 149-200, 2012

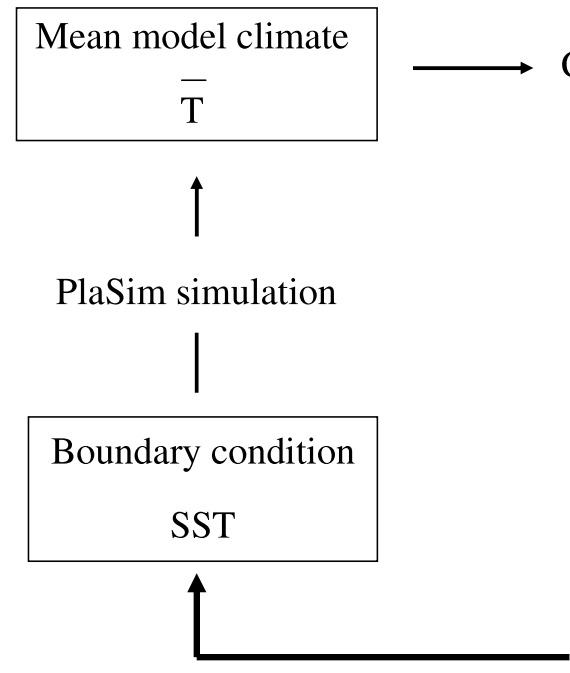

Comparison with proxy data yields

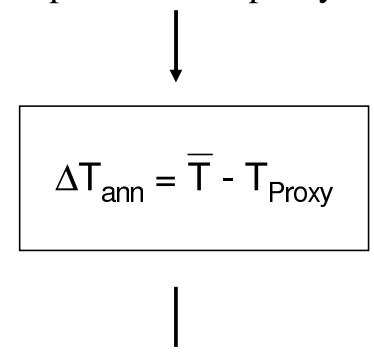

Seasonal sensitivities $\lambda_{\mathrm{s}}$

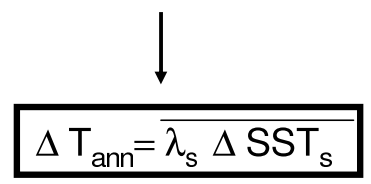

$\Delta \mathrm{SST}$

Fig. 5. Schematic of the adjustment of the SST to the land proxy climate through the inverse modelling procedure. The application of an inverse method is highlighted in bold lettering.

\section{Reconstruction of SST for terrestrial Holocene climate}

K. Haberkorn et al.

\section{Title Page}

Abstract

Introduction

Conclusions

References

Tables

Figures

14

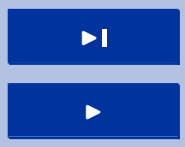

Back

Close

Full Screen / Esc

Printer-friendly Version

Interactive Discussion 


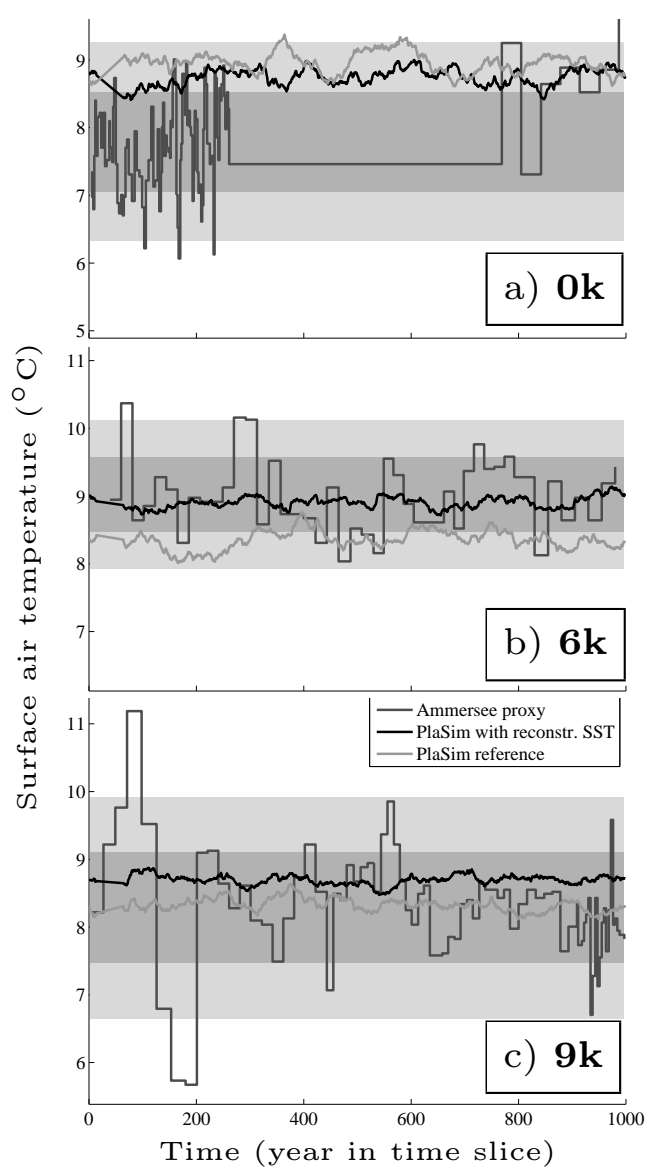

ESDD

3, 149-200, 2012

Reconstruction of SST for terrestrial Holocene climate

K. Haberkorn et al.

Title Page

Abstract

Introduction

Conclusions

References

Tables

Figures
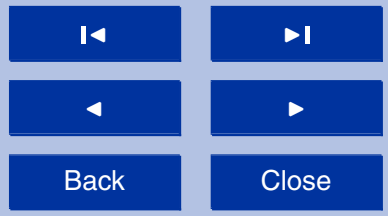

Back

Close

Full Screen / Esc

Printer-friendly Version

Fig. 6. Annual mean surface air temperature $\left({ }^{\circ} \mathrm{C}\right)$ for the Ammersee proxy and the respective PlaSim time series (50 year running mean). Gray shading indicates $1 \sigma$ and $2 \sigma$ ranges in the proxy data set during each millennium.

Interactive Discussion

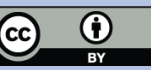



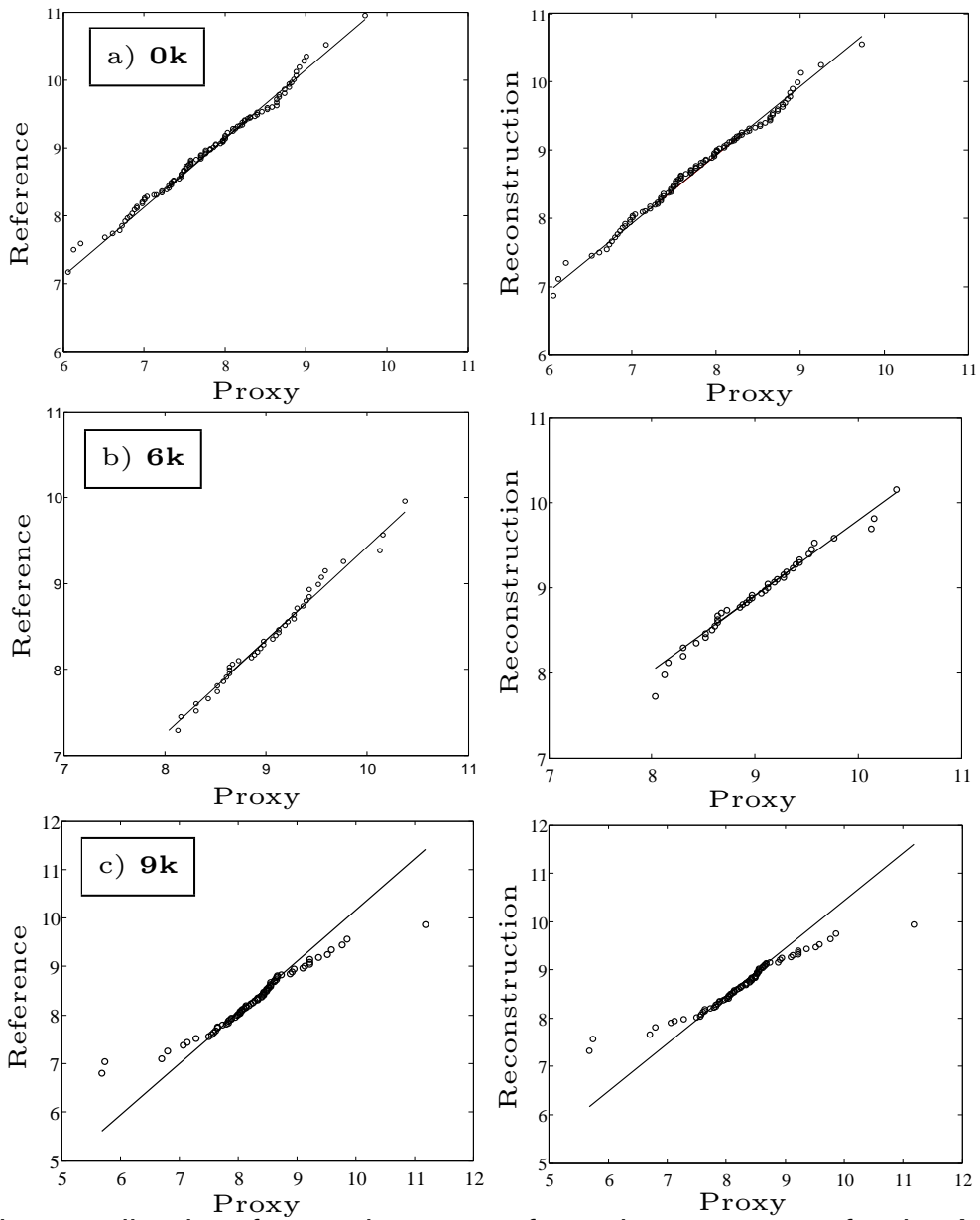

Fig. 7. Quantile quantile plot of annual mean surface air temperature for the Ammersee proxy and the reference simulation time slices (left columns) and the reconstructed time slices (right columns).

ESDD

3, 149-200, 2012

Reconstruction of SST for terrestrial Holocene climate

K. Haberkorn et al.

Title Page

\section{Abstract}

Introduction

Conclusions

References

Tables

Figures
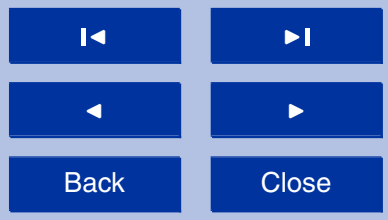

Full Screen / Esc

Printer-friendly Version

Interactive Discussion

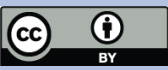




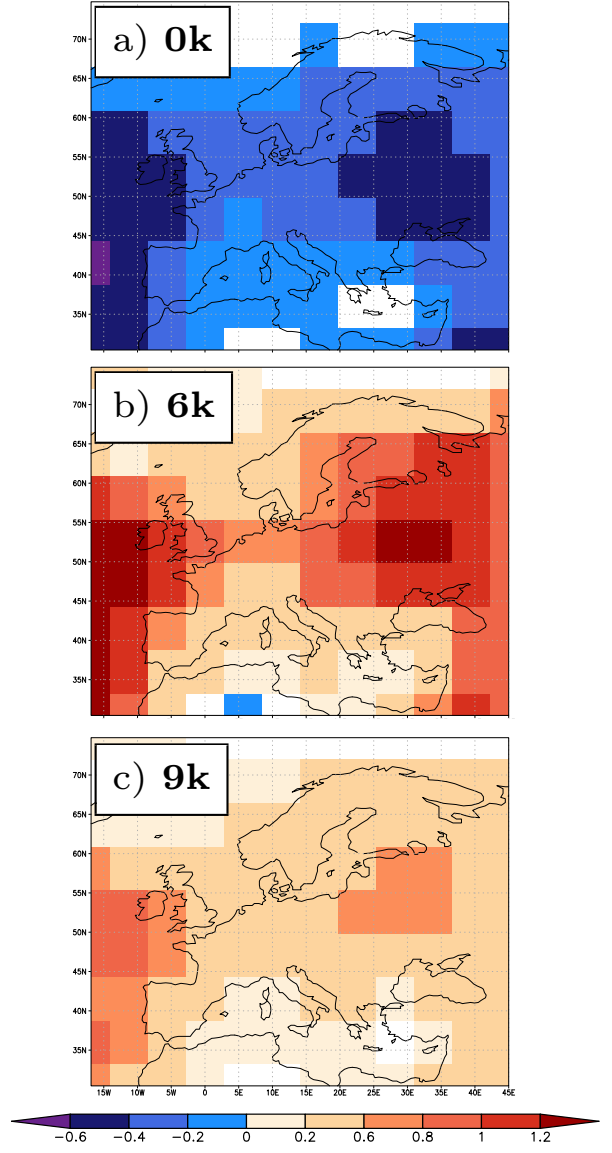

Fig. 8. Surface air temperature anomalies $\left({ }^{\circ} \mathrm{C}\right)$ over Europe between reconstructed time slices and the PlaSim reference simulation at a significance level of $95 \%$ (two-sided t-test, sample size $N=1000$ ). Non-significant regions are indicated in white.

\section{ESDD}

3, 149-200, 2012

\section{Reconstruction of SST for terrestrial Holocene climate}

K. Haberkorn et al.

\section{Title Page}

Abstract

Introduction

Conclusions

References

Tables

Figures

14

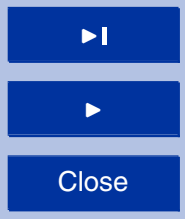

Back

Close

Full Screen / Esc

Printer-friendly Version

Interactive Discussion

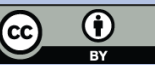



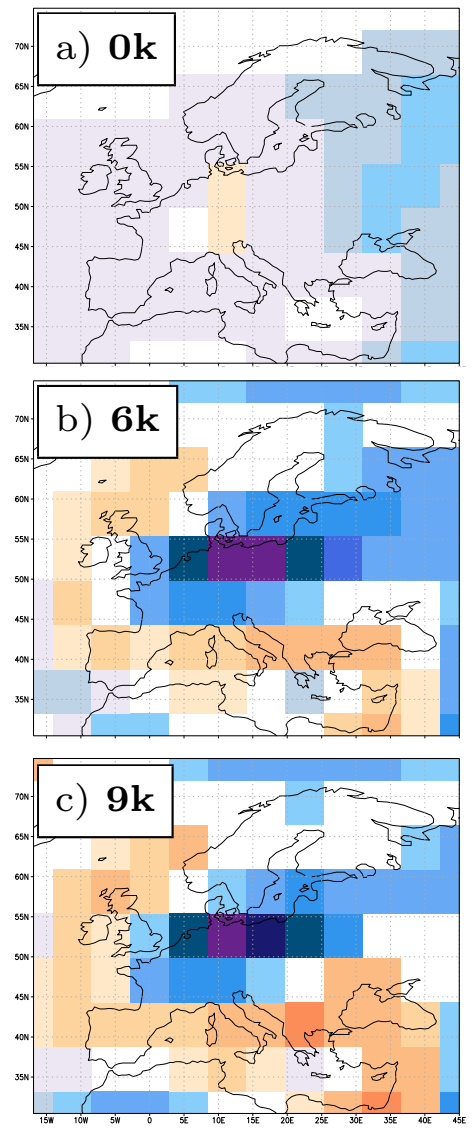

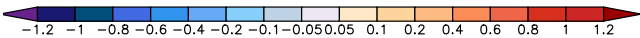

Fig. 9. Surface air temperature anomalies $\left({ }^{\circ} \mathrm{C}\right)$ over Europe between the reference simulation time slices and preindustrial climate at a significance level of $95 \%$ (two-sided t-test, $N=1000$ ). Non-significant regions are indicated in white.
ESDD

3, 149-200, 2012

\section{Reconstruction of SST for terrestrial Holocene climate}

K. Haberkorn et al.

\section{Title Page}

Abstract

Introduction

Conclusions

References

Tables

Figures

14

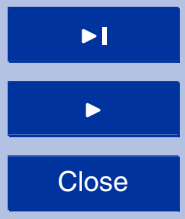

Back

Close

Full Screen / Esc

Printer-friendly Version

Interactive Discussion

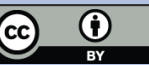




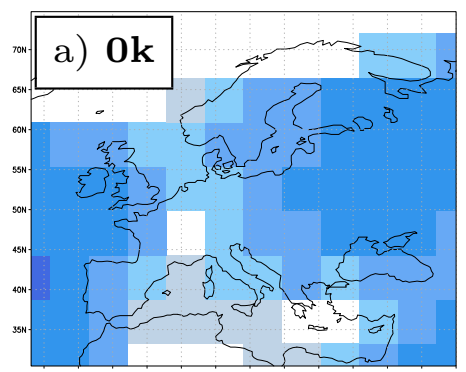

\section{ESDD}

3, 149-200, 2012

\section{Reconstruction of SST for terrestrial Holocene climate}

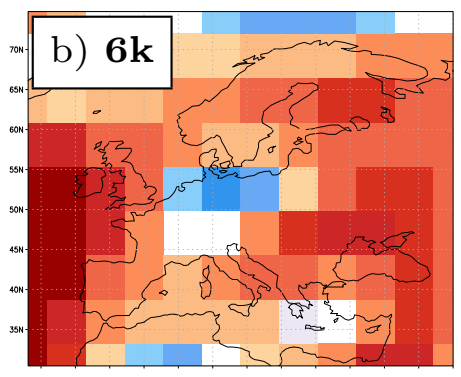

K. Haberkorn et al.

Title Page

\section{Abstract}

Introduction

Conclusions

References

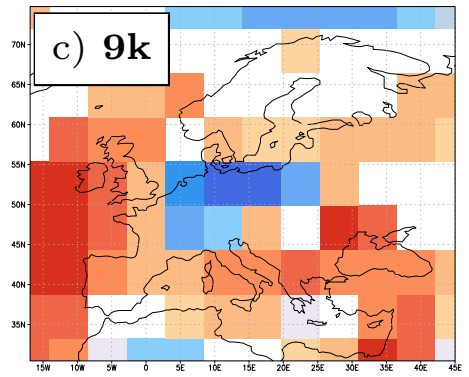

Tables

Figures
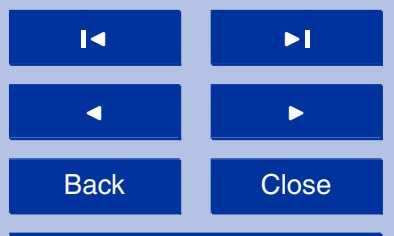

Back

Close

Full Screen / Esc

Printer-friendly Version

Fig. 10. Surface air temperature anomalies $\left({ }^{\circ} \mathrm{C}\right)$ over Europe between the reconstructed time slices and preindustrial climate at a significance level of $95 \%$ (two-sided t-test, $N_{1}=1000$, $N_{2}=200$ ). Non-significant regions are indicated in white.

Interactive Discussion

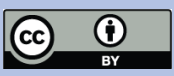

